\title{
The Chemistry of High Valent Tungsten Chlorides with $N$-Substituted Ureas, Including Urea Self-Protonation Reactions Triggered by $\mathrm{WCl}_{6}$
}

\author{
Marco Bortoluzzi, ${ }^{a}$ Fabio Marchetti, ${ }^{, b}$ Guido Pampaloni, ${ }^{b}$ Stefano Zacchini ${ }^{c}$ \\ ${ }^{a}$ Ca' Foscari University of Venice, Dipartimento di Scienze Molecolari e Nanosistemi, Via Torino 155, I-30175 Mestre \\ (Venezia), Italy. \\ ${ }^{b}$ University of Pisa, Dipartimento di Chimica e Chimica Industriale, Via Moruzzi 13, I-56124 Pisa, Italy. Tel: +39 050 \\ 2219245.E-mail: fabio.marchetti1974@unipi.it.Webpage: http://www.dcci.unipi.it/fabio-marchetti.html. \\ c University of Bologna, Dipartimento di Chimica Industriale "Toso Montanari”, Viale Risorgimento 4, I-40136 \\ Bologna, Italy.
}

This submission was created using the RSC Article Template (DO NOT DELETE THIS TEXT)
(LINE INCLUDED FOR SPACING ONLY - DO NOT DELETE THIS TEXT)

The reactions of $\mathrm{WCl}_{6}, \mathrm{WCl}_{5}$ and $\mathrm{WOCl}_{4}$ with a selection of $\mathrm{N}$-substituted ureas (tetramethylurea $=$ tmu; tetraethylurea $=$ teu; 1,3 -diphenylurea $=$ $\mathrm{dpu}$; 1,3-dimethylurea $=\mathrm{dmu}$ ) were performed in chlorinated solvents and then elucidated by means of analytical, spectroscopic and DFT results. The 1:2 molar reactions of $\mathrm{WCl}_{6}$ with, respectively, tmu and dpu proceeded with electron interchange and afforded the salts $\left[(\mathrm{O}-\mathrm{H}-\mathrm{O})-(\mathrm{tmu})_{2}(\mu-\right.$ $\mathrm{H})]\left[\mathrm{WCl}_{6}\right], \mathbf{1 a}\left(40 \%\right.$ yield), and $\left[(O-H-O)-(\mathrm{dpu})_{2}(\mu-\mathrm{H})\right]\left[\mathrm{WCl}_{6}\right], \mathbf{1 b}(65 \%)$. Based on X-ray analyses, the cations in 1a,b consist of a $O-p r o t o n a t e d$ urea forming H-bond with a second urea unit. $[\mathrm{dpu}(O-\mathrm{H})]\left[\mathrm{WCl}_{6}\right], 2$, was obtained $(68 \%$ yield $)$ from $\mathrm{WCl}_{6} / \mathrm{dpu}(1: 1 \mathrm{molar}$ ratio). Dpu itself was identified as the presumably main source of protonation leading to $\mathbf{1 b}$ and $\mathbf{2}$, via $\mathrm{N}-\mathrm{H}$ bond activation and possible involvement of the solvent (dichloromethane). The complexes $\mathrm{WCl}_{5}(\mathrm{urea})$ (urea $=\mathrm{dmu}, \mathbf{3 a} ; \mathrm{tmu}, \mathbf{3 b}$; teu, $\mathbf{3 c}$ ) were isolated in moderate yields by allowing $\mathrm{WCl}_{6}$ to react with the appropriate organic reactant under different experimental conditions. The same complexes 3a-c were obtained in 40-50\% yields from the combinations $\mathrm{WCl}_{5} /$ urea, and few crystals of $\mathrm{WOCl}_{4}(\mathrm{teuH}), 4$, were afforded from $\mathrm{WCl}_{5} / \mathrm{tmu}$ as a result of adventitious hydrolysis. The reactions of $\mathrm{WOCl}_{4}$ with ureas were not selective in general, although $\mathrm{WOCl}_{4}(\mathrm{dmu}), \mathbf{5}$, was isolated in $66 \%$ yield. The X-ray structures determined for 3a and $\mathbf{3 b}$ constitute the first examples of crystallographic characterization of complexes of tungsten pentachloride with a neutral ligand.

\section{Introduction}

Urea and its nitrogen-substituted derivatives ${ }^{1}$ constitute a class of still intensively investigated organic compounds, ${ }^{2}$ that have found applications in biochemistry, ${ }^{3}$ supramolecular chemistry ${ }^{4}$ and organocatalysis. ${ }^{5}$

Ureas hold two potential protonation sites, i.e. the $\mathrm{O}$ and $\mathrm{N}$ atoms, ${ }^{6}$ and protonated ureas are believed to act as possible intermediates in the course of several organic reactions, ${ }^{7}$ and also suitable guest species for nanoporous supramolecular frameworks. ${ }^{8}$

Since ureas are weak bases, strong Brönsted acids have been commonly employed to access the relevant protonated species, ${ }^{9}$ and a number of $O$-protonated ureas were characterized. ${ }^{10}$

We recently reported on the X-ray characterization of a rare $\mathrm{N}$ protonated urea (i.e., tetraethylurea, teu) salt. This compound was obtained by presumable oxidation of the organic precursor by means of $\mathrm{WCl}_{6}$, and evidences were collected for the occurrence of self-protonation via $\mathrm{C}-\mathrm{H}$ bond cleavage. ${ }^{11}$

Indeed tungsten hexachloride $\left(\mathrm{WCl}_{6}\right)$ usually manifests considerable oxidative power due to the relative stability of the +5 and +4 oxidation states, ${ }^{12}$ and clean reduction processes can be achieved by mild reducing agents. ${ }^{13}$ Even tertiary amines are oxidized by $\mathrm{WCl}_{6}$ at room temperature, ${ }^{12 \mathrm{c}}$ and the initial monoelectron transfer from the organic reactant to the tungsten centre may be followed by selective activation reactions. ${ }^{14}$

On the other hand, as a consequence of the hydrophilic nature and the relative weakness of the $\mathrm{W}-\mathrm{Cl}$ bonds, ${ }^{15} \mathrm{WCl}_{6}$ behaves as a powerful chlorinating agent towards the carbonyl function belonging to aldehydes and ketones, ${ }^{16}$ amides, ${ }^{16,17}$ esters,${ }^{18} \alpha$ aminoacids, ${ }^{19}$ and carboxylic acids. ${ }^{20}$ For each of these cases, $\mathrm{Cl} / \mathrm{O}$ interchange between the $\mathrm{W}(\mathrm{VI})$ centre and the organic substrate was clearly ascertained, taking place at room temperature.

In this context, information on the reactivity of $\mathrm{WCl}_{6}$ and, more in general, high valent tungsten chlorides with ureas, in the absence of further reactants, remain quite sparse in the literature. ${ }^{21}$

Herein, we report on an extension of the chemistry of $\mathrm{WCl}_{6}$ with commercial $\mathrm{N}$-substituted ureas (Chart 1), and also $\mathrm{WCl}_{5}$ and $\mathrm{WOCl}_{4}$ have been included in this study. Dichloromethane was selected as solvent, being widely considered non coordinating, ${ }^{22}$ and the privileged medium for $\mathrm{WCl}_{6}$ promoted oxidation reactions. ${ }^{12 \mathrm{c}}$

Protonated urea salts were generally obtained from the reactions with $\mathrm{WCl}_{6}$ in a repeatable manner, presumably via self-protonation processes. DFT calculations were carried out in order to trace a plausible pathway for the $\mathrm{WCl}_{6} / \mathrm{dpu}$ interaction. All the isolated metal products were characterized by analytical and spectroscopic techniques and, in a number of cases, by single crystal X-ray diffraction. The interpretation of diagnostic IR bands was assisted by computer outcomes.<smiles>CN(C)C(=O)N(C)C</smiles>

dpu<smiles>CCN(CC)C(=O)N(CC)CC</smiles>

teu<smiles>CNC(N)=O</smiles>

dmu
Chart 1. Urea derivatives cited in this work

\section{Results and Discussion}

Synthesis and characterization of $\left[\mathrm{WCl}_{6}\right]^{-}$salts of protonated ureas.

In the attempt to replicate the synthesis of the protonated urea salt $\left[\right.$ teuH] $\left[\mathrm{WCl}_{6}\right],{ }^{11}$ we studied the $1: 1$ molar reaction of $\mathrm{WCl}_{6}$ with 
tmu, but this resulted in the formation of a mixture of inseparable products.

In contrast, the 1:2 reaction led us to the isolation of $[(\mathrm{O}-\mathrm{H}-\mathrm{O})$ $\left.(\mathrm{tmu})_{2}(\mu-\mathrm{H})\right]\left[\mathrm{WCl}_{6}\right], \mathbf{1 a}$, in $40 \%$ yield. The analogous salt $[(\mathrm{O}-\mathrm{H}-$ $\left.O)-(\mathrm{dpu})_{2}(\mu-\mathrm{H})\right]\left[\mathrm{WCl}_{6}\right], \mathbf{1 b}$, was afforded in $65 \%$ yield from $\mathrm{WCl}_{6}$ and dpu (Scheme 1).
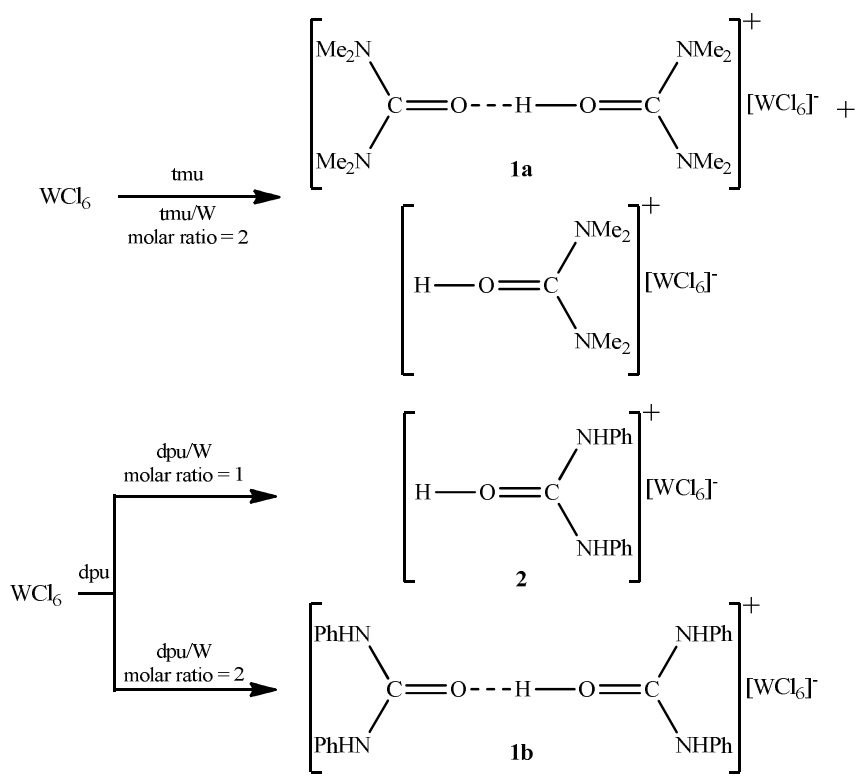

Scheme 1. Synthesis of $O$-protonated ureas.

Crystals of 1a and 1b suitable for X-ray analyses were collected from $\mathrm{CH}_{2} \mathrm{Cl}_{2} /$ hexane mixtures. The solid-state structures of these compounds are shown in Figures 1 and 2, while relevant bonding parameters are provided in Tables 1 and 2. Both structures consist in ionic packings of octahedral $\left[\mathrm{WCl}_{6}\right]^{-}$anions and $\left[\left(\mathrm{O}-\mathrm{H}_{-}\right.\right.$ $\left.O)-(\mathrm{tmu})_{2}(\mu-\mathrm{H})\right]^{+}(\mathbf{1 a})$ or $\left[(O-H-O)-(\mathrm{dpu})_{2}(\mu-\mathrm{H})\right]^{+}(\mathbf{1 b})$ cations. The former $\mathrm{W}(\mathrm{V})$ anion was previously characterized as included in a variety of salts. ${ }^{14,11,23}$ Also the cation in 1a was previously characterized by X-ray, ${ }^{24}$ while the cation in $\mathbf{1 b}$ is unprecedented. Both the cations possess a dimeric nature, and may be viewed as a $\mathrm{O}$-protonated urea molecule forming H-bond with a second urea.

In 1a, the proton $\mathrm{H}(1)$ is statistically disordered over the two $\mathrm{H}$-bonded oxygen atoms, being the two cation subunits related by an inversion centre located in the middle of the $\mathrm{O}(1) \cdots \mathrm{O}(1) \# 1$ vector. The resulting strong $\mathrm{H}$-bond $[\mathrm{O}(1)-\mathrm{H}(1) \quad 0.869(12) \AA$; $\mathrm{H}(1) \cdots \mathrm{O}(1) \# 1$ 1.61(3) $\AA ; \mathrm{O}(1) \cdots \mathrm{O}(1) \# 1$ 2.437(9) $\AA$; O(1)-H(1)$\mathrm{O}(1) \# 1 \quad 159(7)^{\circ}$; \#1 $\left.-\mathrm{x}+2,-\mathrm{y}+1,-\mathrm{z}\right]$ can be classified as a positive charge assisted hydrogen bond (class B), according to Gilli et al. ${ }^{25}$ The $\mathrm{C}(3)$ [sum angles $360(1)^{\circ}$ ], $\mathrm{N}(1)$ [sum angles $358.4(1)^{\circ}$ ] and $\mathrm{N}(2)$ [sum angles $358(1)^{\circ}$ ] atoms display an almost perfect $\mathrm{sp}_{2}$ hybridization and, accordingly, the corresponding $\mathrm{C}(3)-\mathrm{N}(1)$ [1.336(8) $\AA], \mathrm{C}(3)-\mathrm{N}(2)[1.344(8) \AA]$ and $\mathrm{C}(3)-\mathrm{O}(1)[1.289(8) \AA]$ bonds exhibit a significant $\pi$-character. As a consequence of protonation, the $\mathrm{C}(3)-\mathrm{O}(1)$ is significantly shorter than a pure $\mathrm{C}=\mathrm{O}$ double bond $[1.21 \AA] .{ }^{26}$

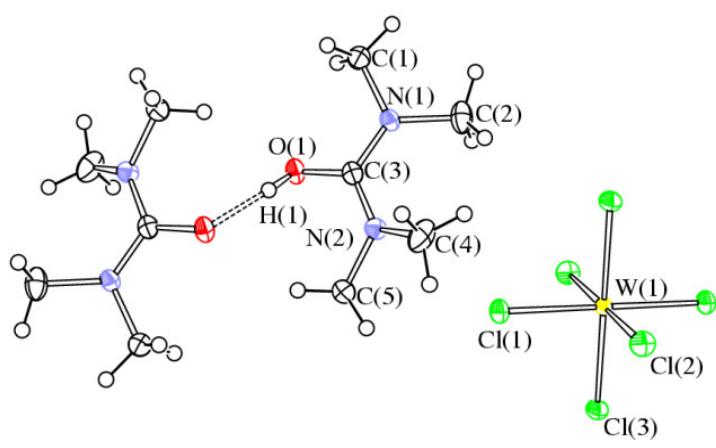

Figure 1. View of the structure of 1a. Displacement ellipsoids are at the $50 \%$ probability level. Only independent atoms have been labelled [W(1) is located on an inversion centre; the second half of the $\mathrm{H}$-bonded $\left[(\mathrm{tmu})_{2} \mathrm{H}\right]^{+}$ cation is generated by an inversion centre close to $\mathrm{H}(1)]$. Hydrogen bond dashed line $\left[\mathrm{O}(1)-\mathrm{H}(1) \quad 0.869(12) \quad \AA ; \quad \mathrm{H}(1) \cdots \mathrm{O}\left(1 \_1\right) \quad 1.61(3) \quad \AA ;\right.$ $\mathrm{O}(1) \cdots \mathrm{O}\left(1 \_1\right) \quad 2.437(9) \quad \AA \quad ; \quad \mathrm{O}(1)-\mathrm{H}(1)-\mathrm{O}\left(1 \_1\right) \quad 159(7)^{\circ} ; \quad$ Symmetry transformation used to generate equivalent atoms $-\mathrm{x}+2,-\mathrm{y}+1,-\mathrm{z}]$.

Table 1. Selected bond lengths $(\AA)$ and angles (deg) for $\mathbf{1 a}$.

\begin{tabular}{llll}
\hline $\mathrm{W}(1)-\mathrm{Cl}(1)$ & $2.3268(16)$ & $\mathrm{W}(1)-\mathrm{Cl}(2)$ & $2.3152(16)$ \\
$\mathrm{W}(1)-\mathrm{Cl}(3)$ & $2.3330(16)$ & $\mathrm{C}(3)-\mathrm{O}(1)$ & $1.289(8)$ \\
$\mathrm{C}(3)-\mathrm{N}(1)$ & $1.336(8)$ & $\mathrm{C}(3)-\mathrm{N}(2)$ & $1.344(8)$ \\
$\mathrm{N}(1)-\mathrm{C}(1)$ & $1.467(8)$ & $\mathrm{N}(1)-\mathrm{C}(2)$ & $1.500(9)$ \\
$\mathrm{N}(2)-\mathrm{C}(4)$ & $1.474(8)$ & $\mathrm{N}(2)-\mathrm{C}(5)$ & $1.465(8)$ \\
& & & \\
$\mathrm{O}(1)-\mathrm{C}(3)-\mathrm{N}(1)$ & $118.2(6)$ & $\mathrm{O}(1)-\mathrm{C}(3)-\mathrm{N}(2)$ & $120.9(6)$ \\
$\mathrm{N}(1)-\mathrm{C}(3)-\mathrm{N}(2)$ & $120.9(6)$ & $\mathrm{C}(3)-\mathrm{N}(1)-\mathrm{C}(1)$ & $119.0(6)$ \\
$\mathrm{C}(3)-\mathrm{N}(1)-\mathrm{C}(2)$ & $127.7(6)$ & $\mathrm{C}(1)-\mathrm{N}(1)-\mathrm{C}(2)$ & $111.7(5)$ \\
$\mathrm{C}(3)-\mathrm{N}(2)-\mathrm{C}(5)$ & $120.0(5)$ & $\mathrm{C}(3)-\mathrm{N}(2)-\mathrm{C}(4)$ & $128.0(6)$ \\
$\mathrm{C}(5)-\mathrm{N}(2)-\mathrm{C}(4)$ & $110.1(5)$ & & \\
\hline
\end{tabular}

In 1b, H-bonding involves the $\mathrm{O}(1)-\mathrm{H}(1)$ and $\mathrm{N}(2)-\mathrm{H}(200)$ groups of the protonated dpu as donors, and the $\mathrm{O}(2)$ site of the other dpu as acceptor. The $\mathrm{N}(3)-\mathrm{H}(300)$ and $\mathrm{N}(4)-\mathrm{H}(400)$ groups of the non protonated dpu are further involved as donors in $\mathrm{H}$ bonds towards the chlorides of the $\left[\mathrm{WCl}_{6}\right]^{-}$anion. Several X-ray crystallographic characterizations of the dpu molecule have been reported, ${ }^{27}$ showing $\mathrm{C}=\mathrm{O}$ and $\mathrm{C}-\mathrm{N}$ distances in the ranges 1.223 1.244 and 1.339-1.374 $\AA$, respectively. O-protonation in $\mathbf{1 b}$ results in a substantial elongation of $\mathrm{C}(1)-\mathrm{O}(1)[1.349(6) \AA]$, whereas $\mathrm{C}(1)-\mathrm{N}(1)[1.324(7) \AA]$ and $\mathrm{C}(1)-\mathrm{N}(2)[1.311(7) \AA]$ are slightly shortened. Also $\mathrm{C}(21)-\mathrm{O}(2)[1.253(6) \AA]$, belonging to the non protonated dpu unit within the cationic dimer, is slightly elongated compared to free dpu, as a result of its involvement in the H-bond.

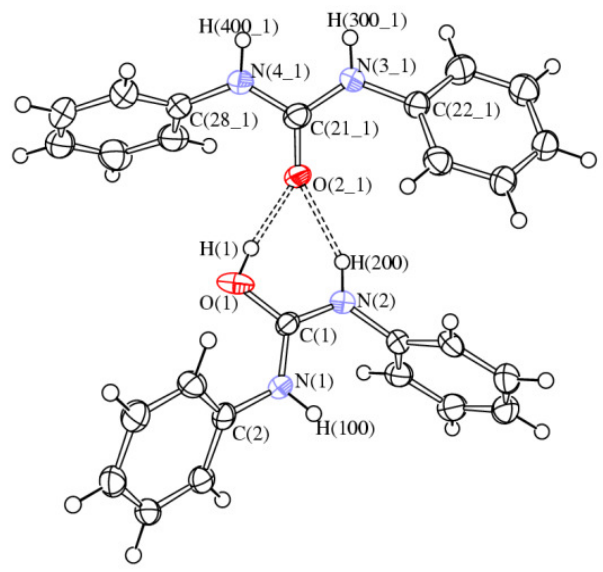




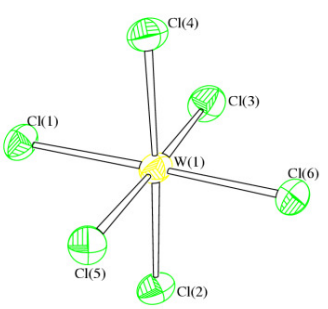

Figure 2. View of the structure of $\mathbf{1 b}$. Displacement ellipsoids are at the 50\% probability level. Only independent atoms have been labelled. Hydrogen bond dashed line $\left[\mathrm{O}(1)-\mathrm{H}(1) \quad 0.835(10) \quad \AA ; \quad \mathrm{H}(1) \cdots \mathrm{O}\left(2 \_1\right) \quad 1.816(19) \quad \AA\right.$; $\mathrm{O}(1) \cdots \mathrm{O}(2 \quad 1) \quad 2.638(6) \quad \AA ; \quad \mathrm{H}(200) \cdots \mathrm{O}(2 \quad 1) \quad 1.99(4) \quad \AA ; \quad \mathrm{N}(2) \cdots \mathrm{O}(2 \quad 1)$ 2.744(6) $\AA ; \mathrm{N}(2)-\mathrm{H}(200) 0.862(19) \AA \AA \mathrm{O}(\overline{1})-\mathrm{H}(1)-\mathrm{O}\left(2 \_1\right) 168(7)^{\circ} ; \mathrm{N}(\overline{2})$ $\mathrm{H}(200)-\mathrm{O}(2-1) \quad 146(5)^{\circ}$; symmetry transformation used to generate equivalent atoms $-\mathrm{x}+1,-\mathrm{y}+1,-\mathrm{z}+1]$.

Table 2. Selected bond lengths $(\AA)$ and angles (deg) for $\mathbf{1 b}$.

\begin{tabular}{llll}
\hline $\mathrm{W}(1)-\mathrm{Cl}(1)$ & $2.3884(16)$ & $\mathrm{W}(1)-\mathrm{Cl}(2)$ & $2.3272(15)$ \\
$\mathrm{W}(1)-\mathrm{Cl}(3)$ & $2.2758(18)$ & $\mathrm{W}(1)-\mathrm{Cl}(4)$ & $2.3514(15)$ \\
$\mathrm{W}(1)-\mathrm{Cl}(5)$ & $2.3548(17)$ & $\mathrm{W}(1)-\mathrm{Cl}(6)$ & $2.3105(16)$ \\
$\mathrm{C}(1)-\mathrm{O}(1)$ & $1.349(6)$ & $\mathrm{C}(21)-\mathrm{O}(2)$ & $1.253(6)$ \\
$\mathrm{C}(1)-\mathrm{N}(1)$ & $1.324(7)$ & $\mathrm{C}(21)-\mathrm{N}(3)$ & $1.360(8)$ \\
$\mathrm{C}(1)-\mathrm{N}(2)$ & $1.311(7)$ & $\mathrm{C}(21)-\mathrm{N}(4)$ & $1.361(7)$ \\
& & & \\
$\mathrm{O}(1)-\mathrm{C}(1)-\mathrm{N}(1)$ & $117.3(5)$ & $\mathrm{O}(2)-\mathrm{C}(21)-\mathrm{N}(3)$ & $123.5(5)$ \\
$\mathrm{O}(1)-\mathrm{C}(1)-\mathrm{N}(2)$ & $121.2(5)$ & $\mathrm{O}(2)-\mathrm{C}(21)-\mathrm{N}(4)$ & $121.6(6)$ \\
$\mathrm{N}(1)-\mathrm{C}(1)-\mathrm{N}(2)$ & $121.5(5)$ & $\mathrm{N}(3)-\mathrm{C}(21)-\mathrm{N}(4)$ & $114.8(5)$ \\
\hline
\end{tabular}

Compounds 1a-b were characterized, in the solid state, by magnetic analysis and IR spectroscopy too. The magnetic susceptivity values are as expected for $\left[\mathrm{WCl}_{6}\right]^{-}$salts. ${ }^{11,14,23 \mathrm{~d}, 28}$

The IR spectra of $\mathbf{1 a}$ and $\mathbf{1 b}$ display several strong absorptions in the region $1700-1550 \mathrm{~cm}^{-1}$. With the assistance of DFT simulations, they have been attributed to $\mathrm{C}=\mathrm{O}$ and $\mathrm{C}=\mathrm{N}$ stretching and $\mathrm{O}-\mathrm{H}$ bending vibrations. In the case of $\mathbf{1 b}$, also the $\mathrm{N}-\mathrm{H}$ bending modes contribute to this region of the spectrum.

According to the IR spectrum recorded on the residue derived from the reaction mixture $\mathrm{WCl}_{6} / \mathrm{tmu}$, the $\mathrm{O}-\mathrm{H}-\mathrm{O}$ cation as found in $\mathbf{1 a}$ is co-produced in admixture with a small amount of the cation $[\operatorname{tmu}(O-\mathrm{H})]^{+}($Scheme 1$) .^{11}$

The reaction of $\mathrm{WCl}_{6}$ with dpu was studied also in 1:1 ratio, and led to the isolation of a solid material which was identified as the monomer $[\mathrm{dpu}(O-\mathrm{H})]\left[\mathrm{WCl}_{6}\right], 2$ (Scheme 1). According to DFT calculations, the $O$-protonated form of 2, shown in Figure 3, is more stable than the $N$-protonated isomer by about $4.4 \mathrm{kcal} \mathrm{mol}^{-1}$ (Figure S1 and Table S1).

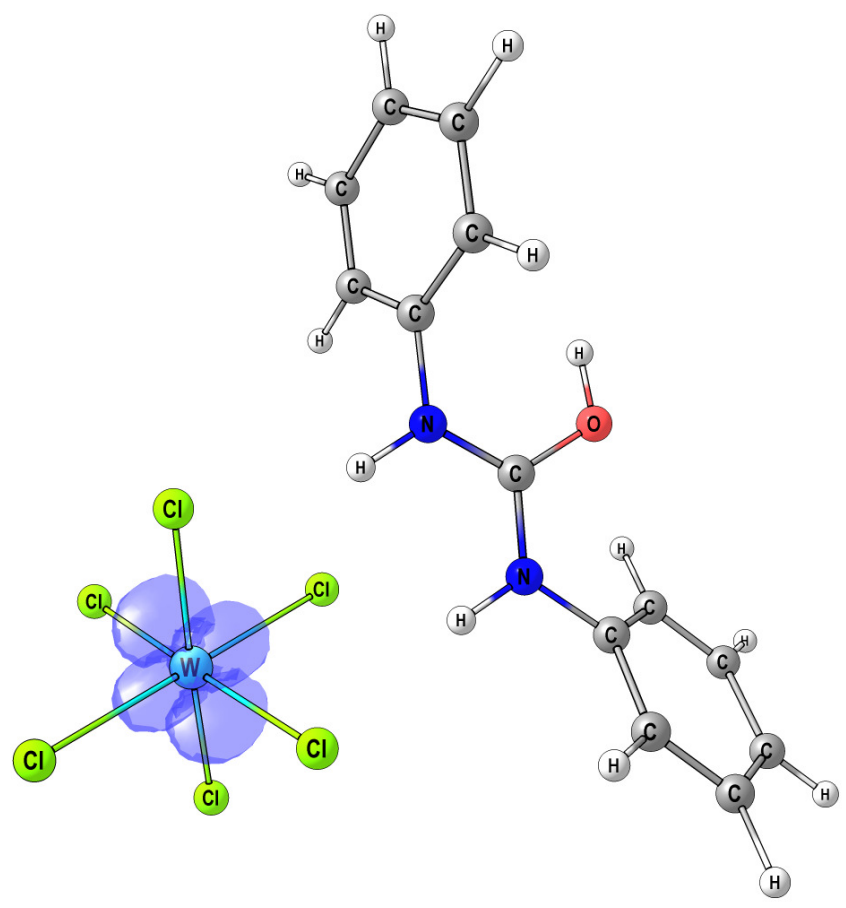

Figure 3. DFT-optimized geometry (C-PCM/ $\omega \mathrm{B} 97 \mathrm{X}$ calculation, $\mathrm{CH}_{2} \mathrm{Cl}_{2}$ as implicit solvent) of $[\mathrm{dpuH}]\left[\mathrm{WCl}_{6}\right], 2$, with spin density surface (isovalue $=0.01$ a.u.). Selected computed bond lengths $(\AA)$ : $\mathrm{C}-\mathrm{O} 1.309$; C-N 1.323, 1.330; N-H 1.019, 1.019; O-H 0.971; W-Cl 2.272, 2.309 $2.311,2.315,2.391,2.399 ; \mathrm{H}---\mathrm{Cl}$ (shortest) 2.292, 2.342. Selected computed angles $\left({ }^{\circ}\right)$ : N-C-O 117.5, 121.3; N-C-N 121.2.

The IR spectrum of 2 shows a strong band at $1609 \mathrm{~cm}^{-1}$, attributed to the $[\mathrm{NCN}]$ moiety. Salient ${ }^{13} \mathrm{C}$ NMR feature is given by the protonated carbonyl carbon, whose resonance has been found at $214.1 \mathrm{ppm}$.

We have previously suggested that self O-protonation is working when tmu is allowed to contact with $\mathrm{WCl}_{6}$, due to $\mathrm{Csp} p^{3}-\mathrm{H}$ activation. ${ }^{11}$ Here, we carried out DFT ( $\omega$ B97X functional, C-PCM solvation model for dichloromethane) and IR and NMR experiments, in order to elucidate the interaction of $\mathrm{WCl}_{6}$ with dpu, containing $\mathrm{NH}$ units. It is likely that the first step consists in oneelectron exchange, leading to the $\mathrm{W}(\mathrm{V})$ salt $[\mathrm{dpu}]\left[\mathrm{WCl}_{6}\right](\Delta \mathrm{G}=$ $-0.3 \mathrm{kcal} \mathrm{mol}^{-1}$ ). This process should take place in two steps: 1) initial formation of the outer-sphere complex $\mathrm{WCl}_{6}$-dpu $(\Delta \mathrm{G}=12.1$

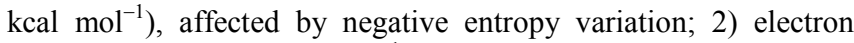
transfer $\left(-12.4 \mathrm{kcal}^{\mathrm{mol}}{ }^{-1}\right)$. The calculated structure of $[\mathrm{dpu}]\left[\mathrm{WCl}_{6}\right]$ is shown in Figure 4 together with its spin density surface. The unpaired electron on the organic cation appears mainly localized on a p-type orbital at the nitrogen atom and on the adjacent phenyl ring. 


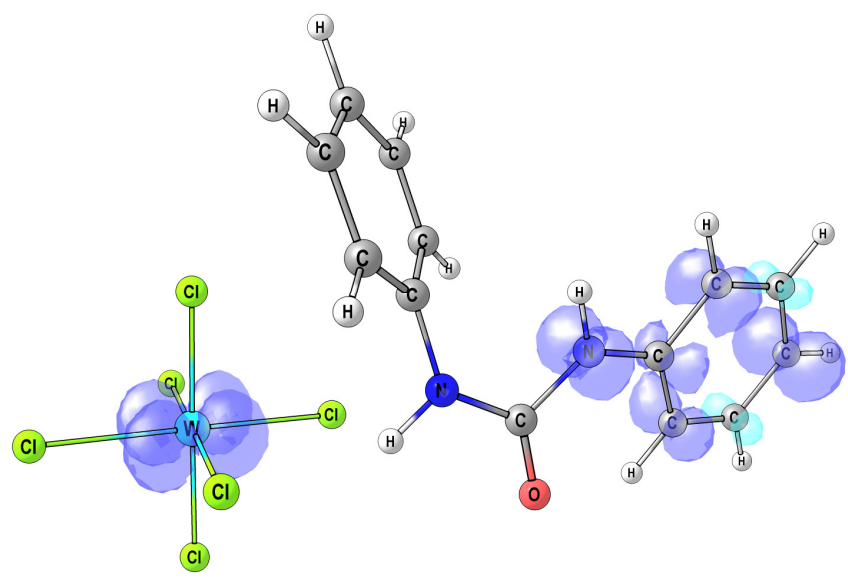

Figure 4. DFT-optimized geometry (C-PCM/ $\omega$ B $97 \mathrm{X}$ calculation, $\mathrm{CH}_{2} \mathrm{Cl}_{2}$ as implicit solvent) of $[\mathrm{dpu}]\left[\mathrm{WCl}_{6}\right]$, with spin density surface (isovalue $=$ 0.01 a.u.). Selected computed bond lengths $(\AA)$ : C-O 1.214; C-N 1.346, 1.443; N-H 1.017, 1.018; W-Cl 2.289, 2.299, 2.330, 2.340, 2.352, 2.381; $\mathrm{H}---\mathrm{Cl}$ (shortest) 2.406. Selected computed angles $\left({ }^{\circ}\right)$ : $\mathrm{N}-\mathrm{C}-\mathrm{O}$ 121.6, 125.6; N-C-N 112.8.

Different pathways were considered starting from $[\mathrm{dpu}]\left[\mathrm{WCl}_{6}\right]$ and leading to the protonated urea salt $\mathbf{2}$, that may be viewed as the precursor of $\mathbf{1 b}$ by addition of a further dpu unit. ${ }^{29}$

The occurrence of dehydrogenative intermolecular aryl-aryl coupling ${ }^{30}$ could be ruled out by NMR evidence. Instead, adventitious water might in principle act as a protonation source. Nevertheless this contribution, even though present, should be negligible. In fact, simple $\mathrm{WCl}_{6}$ derivatives contaminated with water/moisture air readily convert into oxide chloride species, ${ }^{12 \mathrm{~d}, 31}$ which exhibit a diagnostic, intense IR band around 980-1000 $\mathrm{cm}^{-1}$, accounting for the [W=O] bond. ${ }^{16,18,19,20}$ The IR spectrum of the residue obtained from the $1: 1 \mathrm{WCl}_{6} / \mathrm{dpu}$ reaction mixture did not contain any significant absorption within the interval 970-1010 $\mathrm{cm}^{-1}$.

In accordance with previous findings on the reactivity of $\mathrm{WCl}_{6}$ with tertiary amines, ${ }^{14}$ the formation of 2 might proceed from $[\mathrm{dpu}]\left[\mathrm{WCl}_{6}\right]$ and the outer-sphere complex $\mathrm{WCl}_{6}$-dpu (Eqn. $1, \Delta \mathrm{G}$ $=-4.4 \mathrm{kcal} \mathrm{mol}^{-1}$ ). A NH group of the latter would be involved in hydrogen transfer to the former.

$[\mathrm{dpu}]\left[\mathrm{WCl}_{6}\right]+\mathrm{WCl}_{6}-\mathrm{dpu} \rightarrow[\mathrm{dpuH}]\left[\mathrm{WCl}_{6}\right]+[\mathrm{PhNC}(\mathrm{O}) \mathrm{NHPh}]\left[\mathrm{WCl}_{6}\right](1)$

The optimized structure of the expected co-product $[\mathrm{PhNC}(\mathrm{O}) \mathrm{NHPh}]\left[\mathrm{WCl}_{6}\right]\left(\right.$ Eqn. 1) is shown in Figure $5 .^{32}$

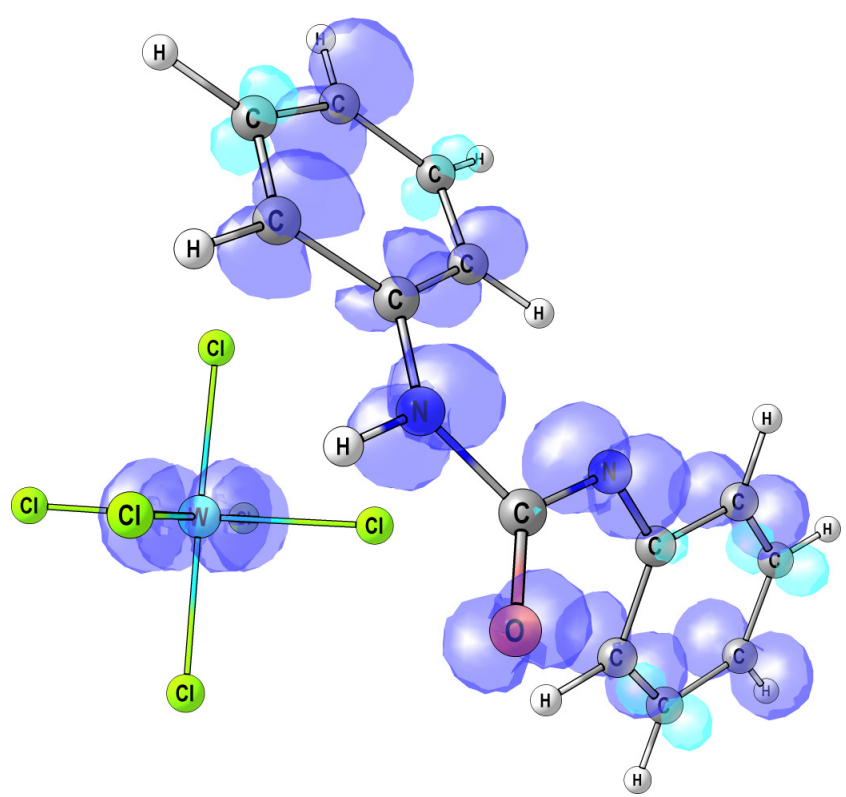

Figure 5. DFT-optimized geometry (C-PCM/ $\omega \mathrm{B} 97 \mathrm{X}$ calculation, $\mathrm{CH}_{2} \mathrm{Cl}_{2}$ as implicit solvent) of $[\mathrm{PhNC}(\mathrm{O}) \mathrm{NHPh}]\left[\mathrm{WCl}_{6}\right]$, with spin density surface (isovalue $=0.01$ a.u.). Selected computed bond lengths $(\AA)$ : $\mathrm{C}-\mathrm{O} 1.216$; $\mathrm{C}-\mathrm{N}(\mathrm{H})$ 1.438; C-N 1.362; N-H 1.018; W-Cl 2.292, 2.303, 2.331, 2.332, 2.365, 2.366; $\mathrm{H}---\mathrm{Cl}$ (shortest) 2.934. Selected computed angles $\left(^{\circ}\right)$ : $\mathrm{N}(\mathrm{H})-\mathrm{C}-\mathrm{O} 1115.3 ; \mathrm{N}-\mathrm{C}-\mathrm{O} 128.9 ; \mathrm{N}-\mathrm{C}-\mathrm{N} 115.4$.

Reaction (1) results from the sum of two sub-reactions, i.e. the hydrogen abstraction by $[\mathrm{dpu}]^{+}$and the reduction of $\mathrm{WCl}_{6}$. This implies that, in principle, the $[\mathrm{dpu}]^{+}$cation may be involved in two different, initial processes, that are represented by Eqns. 2 and 3, respectively.

$[\mathrm{dpu}]^{+}+\mathrm{dpu} \rightarrow[\mathrm{dpuH}]^{+}+\mathrm{PhNC}(\mathrm{O}) \mathrm{NHPh}$

$\Delta \mathrm{G}=8.0 \mathrm{kcal} \mathrm{mol}^{-1}$

$[\mathrm{dpu}]^{+}+\mathrm{WCl}_{6} \rightarrow[\mathrm{dpu}]^{2+}+\left[\mathrm{WCl}_{6}\right]^{-}$

$\Delta \mathrm{G}=16.6 \mathrm{kcal} \mathrm{mol}^{-1}$

The DFT-optimized geometries of $[\mathrm{dpu}]^{2+}$ and $\mathrm{PhNC}(\mathrm{O}) \mathrm{NHPh}$ are shown in Figures $\mathrm{S} 2$ and $\mathrm{S} 3$, respectively. The computed $\Delta \mathrm{G}$ variations (compare Eqn. 2 to Eqn. 3) suggest that proton transfer is the most likely initial step of the overall reaction reported in Eqn. 1.

The possible urea-descending compound $[\mathrm{PhNC}(\mathrm{O}) \mathrm{NHPh}]^{+}$is expected to be a highly reactive species, presumably quenched by the solvent via transfer of hydrogen or alkyl units. ${ }^{34}$ In accordance with this hypothesis, after addition of water to the $1: 1 \mathrm{WCl}_{6} / \mathrm{dpu}$ reaction mixture, ${ }^{35,36}$ we recognized minor amounts of probable $N$ alkylated compounds, apart from dpu (major). In particular, the ${ }^{1} \mathrm{H}$ NMR spectrum (in $\mathrm{CDCl}_{3}$ ) exhibited a singlet at $2.87 \mathrm{ppm}$, correlating to ${ }^{13} \mathrm{C}$ NMR resonances at $38.3 \mathrm{ppm}$ (HSQC correlation) and $154.0 \mathrm{ppm}$ (carbonyl unit, HMBC correlation). A further investigation (mass spectrometry) aimed to identify these species did not provide conclusive results. In agreement with the idea that dichloromethane is involved in the synthesis of $\mathbf{1 b}$ and $\mathbf{2}$, the $1: 1$ reaction of $\mathrm{WCl}_{6}$ with $\mathrm{dpu}$, performed in hexane, sluggishly gave 2 in low yield (ca. $30 \%$, reaction time $=48 \mathrm{~h}$ ), together with a complicated mixture of non identified products.

\section{Coordination chemistry of $\mathrm{WCl}_{5}$ with ureas.}

It seems that the $1: 1$ reaction of $\mathrm{WCl}_{6}$ with dmu proceeds to some extent giving $[\mathrm{dmuH}]\left[\mathrm{WCl}_{6}\right]$. Basically, dmu contains a double source for potential self-protonation, i.e. the $\mathrm{NH}$ (compare dpu) and $\alpha-\mathrm{CH}$ (compare tmu, teu) groups. Indeed the IR spectrum of the solid residue obtained from the reaction indicated the presence 
of a mixture of products, presumably including $[\mathrm{dmuH}]^{+}$(band at $1660 \mathrm{~cm}^{-1}$ ). Nevertheless, an attempt of crystallization afforded a moderate amount of the $\mathrm{W}(\mathrm{V})$ complex $\mathrm{WCl}_{5}(\mathrm{dmu})$, 3a. This outcome is in alignment with DFT calculations pointing that the dehydrochlorination of $[\mathrm{ureaH}]\left[\mathrm{WCl}_{6}\right]$ compounds is a feasible reaction (Scheme 2).

\begin{tabular}{ccc}
\multicolumn{3}{c}{$[$ ureaH $]\left[\mathrm{WCl}_{6}\right] \rightarrow \mathrm{WCl}_{5}($ urea $)+\mathrm{HCl}$} \\
Compound & urea & $\Delta \mathrm{G}\left(\mathrm{kcal} \mathrm{mole}^{-1}\right)$ \\
\hline 3a & $\mathrm{dmu}$ & -15.4 \\
3b & tmu & -14.0 \\
3c & teu & -13.0 \\
\hline
\end{tabular}

Scheme 2. Favourable release of $\mathrm{HCl}$ from $\left[\mathrm{WCl}_{6}\right]^{-}$salts of protonated ureas.

In an attempt to straightforwardly reproduce the synthesis of 3a-c, we subjected to thermal treatment the $1: 1$ mixtures $\mathrm{WCl}_{6} /$ urea. Although a clean product was not obtained from the combination $\mathrm{WCl}_{6} / \mathrm{dmu}$, heating the $1: 1$ mixtures $\mathrm{WCl}_{6} / \mathrm{tmu}$ and $\mathrm{WCl}_{6} /$ teu gave the complexes $\mathrm{WCl}_{5}(\mathrm{tmu}), \mathbf{3 b}$, and $\mathrm{WCl}_{5}(\mathrm{teu}), \mathbf{3} \mathbf{c}$, in moderate yields.

Crystals of 3a and 3b suitable for X-ray diffraction analysis could be collected, providing the first crystallographic characterizations of tungsten $(\mathrm{V})$ complexes of general formula $\mathrm{WCl}_{5} \mathrm{~L}(\mathrm{~L}=$ neutral ligand) ever reported. The structures of $\mathbf{3} \mathbf{a}$ and $\mathbf{3 b}$ (Figures 6 and 7 , Table 3) display two different types of $\mathrm{W}-\mathrm{Cl}$ bonds, being $\mathrm{W}(1)-\mathrm{Cl}(1)$ [2.275(4) $\AA$ in 3a, 2.2819(14) $\AA$ in 3b], trans to the Odonor ligand, sensibly shorter compared to the remaining $\mathrm{W}-\mathrm{Cl}$ distances [ranges 2.314(4)-2.370(4) $\AA$ in 3a and 2.3323(14)$2.3403(13) \AA$ in $3 \mathbf{b}]$. The $\mathrm{C}(1)-\mathrm{O}(1)$ distance $[1.280(17)$ and $1.319(6) \AA$ in 3a and 3b, respectively] is typical for a double $\mathrm{C}=\mathrm{O}$ bond. ${ }^{26}$ The $\mathrm{N}(1)-\mathrm{H}(1)$ and $\mathrm{N}(2)-\mathrm{H}(2)$ units within the dmu ligand of $3 \mathbf{a}$ are involved as donors in both inter- and intra-molecular $\mathrm{H}-$ bonds towards the chloride ligands.

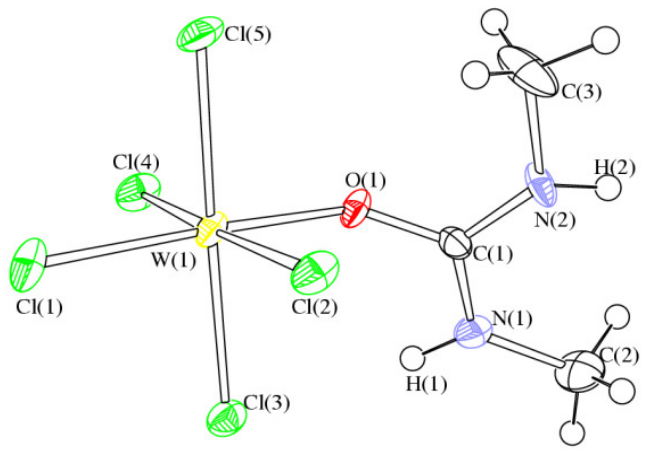

Figure 6. View of the molecular structure of 3a, with key atoms labeled. Displacement ellipsoids are at the $50 \%$ probability level.

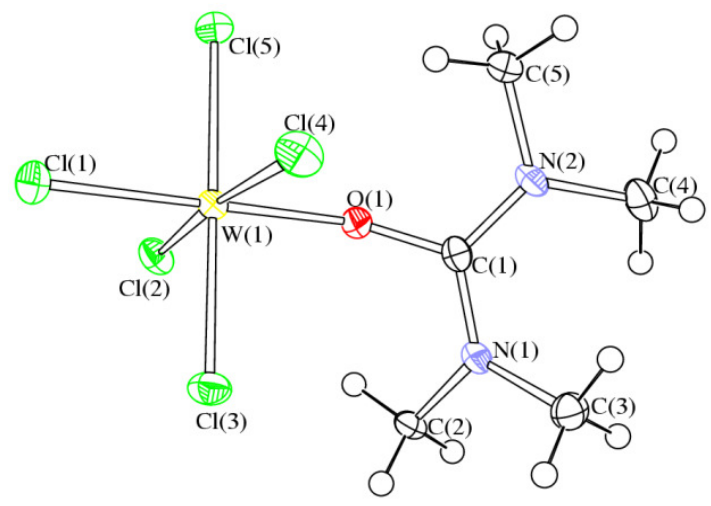

Figure 7. View of the molecular structure of $\mathbf{3 b}$, with key atoms labeled. Displacement ellipsoids are at the $50 \%$ probability level.

Table 3. Selected bond lengths $(\AA)$ and angles $\left(^{\circ}\right)$ for $\mathbf{3 a}$ and $\mathbf{3 b}$

\begin{tabular}{lll}
\hline & $\mathbf{3 a}$ & $\mathbf{3 b}$ \\
\hline $\mathrm{W}(1)-\mathrm{Cl}(1)$ & $2.275(4)$ & $2.2819(14)$ \\
$\mathrm{W}(1)-\mathrm{Cl}(2)$ & $2.370(4)$ & $2.3327(13)$ \\
$\mathrm{W}(1)-\mathrm{Cl}(3)$ & $2.328(4)$ & $2.3344(14)$ \\
$\mathrm{W}(1)-\mathrm{Cl}(4)$ & $2.347(3)$ & $2.3403(13)$ \\
$\mathrm{W}(1)-\mathrm{Cl}(5)$ & $2.314(4)$ & $2.3323(14)$ \\
$\mathrm{W}(1)-\mathrm{O}(1)$ & $1.932(10)$ & $1.939(3)$ \\
$\mathrm{O}(1)-\mathrm{C}(1)$ & $1.280(17)$ & $1.319(6)$ \\
$\mathrm{C}(1)-\mathrm{N}(1)$ & $1.327(19)$ & $1.335(7)$ \\
$\mathrm{C}(1)-\mathrm{N}(2)$ & $1.340(18)$ & $1.317(6)$ \\
& & \\
$\mathrm{Cl}(1)-\mathrm{W}(1)-\mathrm{O}(1)$ & $177.5(3)$ & $179.38(11)$ \\
$\mathrm{Cl}(2)-\mathrm{W}(1)-\mathrm{Cl}(4)$ & $175.27(15)$ & $173.46(5)$ \\
$\mathrm{Cl}(3)-\mathrm{W}(1)-\mathrm{Cl}(5)$ & $177.64(15)$ & $178.43(5)$ \\
$\mathrm{W}(1)-\mathrm{O}(1)-\mathrm{C}(1)$ & $143.2(10)$ & $147.1(3)$ \\
$\mathrm{O}(1)-\mathrm{C}(1)-\mathrm{N}(1)$ & $118.8(13)$ & $118.1(4)$ \\
$\mathrm{O}(1)-\mathrm{C}(1)-\mathrm{N}(2)$ & $120.5(14)$ & $117.7(4)$ \\
$\mathrm{N}(1)-\mathrm{C}(1)-\mathrm{N}(2)$ & $120.7(14)$ & $124.2(4)$ \\
\hline
\end{tabular}

It should be remarked that the chemistry of tungsten pentachloride has been limitedly developed heretofore. Indeed only few coordination adducts were claimed to be prepared from $\mathrm{WCl}_{6} \cdot{ }^{37}$ As an alternative route to $\mathrm{WCl}_{5}$ (urea) complexes, first we prepared $\mathrm{WCl}_{5}$ from commercial $\mathrm{WCl}_{6}$ according to a reported procedure, ${ }^{38}$ then $\mathrm{WCl}_{5}$ was allowed to interact with, respectively, dmu, tmu and teu in dichloromethane. The reactions did proceed with limited selectivity and the expected complexes 3a-c were afforded in 40 $50 \%$ yields (Eqn. 4 ).

$\begin{array}{cc}\mathrm{WCl}_{5}+\underset{\text { urea }}{\mathrm{dmu}} & \rightarrow \mathrm{WCl}_{5} \text { (urea) } \\ \text { tmu } & \mathbf{3 a} \\ \text { teu } & \mathbf{3 b} \\ & \mathbf{3 c}\end{array}$

An attempt of crystallization from the $\mathrm{WCl}_{5} / \mathrm{tmu}$ reaction mixture provided few X-ray quality crystals of $\mathrm{WOCl}_{4}(\mathrm{teuH}), \mathbf{4}$, produced as a consequence of fortuitous hydrolysis.

The molecular structure is shown in Figure 8, while relevant bonding parameters are reported in Table 4 . Compound $\mathbf{4}$ may be viewed as a zwitterionic complex composed by an anionic $\left[\mathrm{WOCl}_{4}\right]^{-}$moiety bonded to a N-protonated $[\mathrm{teuH}]^{+}$cation. The $\mathrm{W}(1)$ centre displays a distorted octahedral coordination with the two O-donor ligands in trans position, as found in other $\left[\mathrm{WOCl}_{4}(\mathrm{~L})\right]^{-}$complexes $(\mathrm{L}=$ neutral ligand). ${ }^{39}$ The $\mathrm{H}(1)$ hydrogen has been preliminarily located in the Fourier Difference Map and then refined by a riding model. Its presence is further corroborated by the presence of a weak intermolecular $\mathrm{H}$-bond involving $\mathrm{N}(1)-\mathrm{H}(1)$ and the chloride ligand of an adjacent complex $[\mathrm{N}(1)-\mathrm{H}(1) \quad 0.93 \AA, \mathrm{H}(1) \cdots \mathrm{Cl}(3) \# 1 \quad 2.42 \AA$, $\mathrm{N}(1) \cdots \mathrm{Cl}(3) \# 1 \quad 3.254(3) \AA,<\mathrm{N}(1) \mathrm{H}(1) \mathrm{Cl}(3) \# 1 \quad 146.9^{\circ}$, Symmetry transformation \#1: $\mathrm{x}-1 / 2,-\mathrm{y}+1 / 2, \mathrm{z}-1 / 2]$. Moreover, the $\mathrm{C}(1)-\mathrm{N}(1)$ contact [1.495(4) $\AA$ ], involving the protonated nitrogen, is typical for a $\mathrm{C}\left(\mathrm{sp}^{2}\right)-\mathrm{N}\left(\mathrm{sp}^{3}\right)$ bond, whereas $\mathrm{C}(1)-\mathrm{N}(2)[1.313(4) \AA]$ is shorter in view of a partial $\pi$-interaction between $\mathrm{C}(1)$ and the lone pair on $\mathrm{N}(2) .{ }^{19}$ In agreement with this, $\mathrm{C}(1)$ [sum angles $360.0(5)^{\circ}$ ] and $\mathrm{N}(2)$ [sum angles $359.9(5)^{\circ}$ ] display a perfect $\mathrm{sp}_{2}$ hybridization, whereas $\mathrm{N}(1)$ [sum angles $333.4(5)^{\circ}$ ] is $\mathrm{sp}^{3}$ hybridized. 


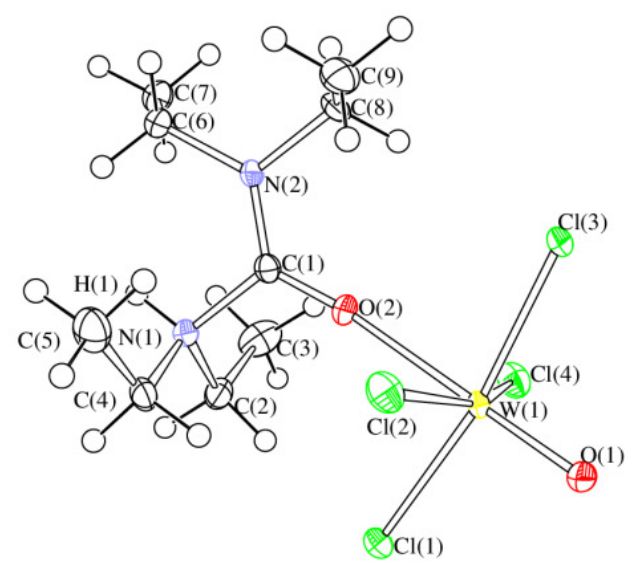

Figure 8. Molecular structure of $\mathbf{4}$, with key atoms labelled. Thermal ellipsoids are at the $50 \%$ probability level

Table 4. Selected bond distances $(\AA)$ and angles $\left(^{\circ}\right)$ for 4.

\begin{tabular}{llll}
$\mathrm{W}(1)-\mathrm{O}(1)$ & $1.681(2)$ & $\mathrm{W}(1)-\mathrm{O}(2)$ & $2.292(2)$ \\
$\mathrm{W}(1)-\mathrm{Cl}(1)$ & $2.3761(8)$ & $\mathrm{W}(1)-\mathrm{Cl}(2)$ & $2.3584(8)$ \\
$\mathrm{W}(1)-\mathrm{Cl}(3)$ & $2.4126(7)$ & $\mathrm{W}(1)-\mathrm{Cl}(4)$ & $2.3627(8)$ \\
$\mathrm{C}(1)-\mathrm{O}(2)$ & $1.219(3)$ & $\mathrm{C}(1)-\mathrm{N}(1)$ & $1.495(4)$ \\
$\mathrm{C}(1)-\mathrm{N}(2)$ & $1.313(4)$ & $\mathrm{N}(2)-\mathrm{C}(6)$ & $1.493(4)$ \\
$\mathrm{N}(2)-\mathrm{C}(8)$ & $1.483(4)$ & $\mathrm{N}(1)-\mathrm{C}(2)$ & $1.515(4)$ \\
$\mathrm{N}(1)-\mathrm{C}(4)$ & $1.520(4)$ & & \\
& & & \\
$\mathrm{O}(1)-\mathrm{W}(1)-\mathrm{O}(2)$ & $179.37(9)$ & $\mathrm{Cl}(1)-\mathrm{W}(1)-\mathrm{Cl}(3)$ & $170.38(3)$ \\
$\mathrm{Cl}(2)-\mathrm{W}(1)-\mathrm{Cl}(4)$ & $159.39(3)$ & $\mathrm{W}(1)-\mathrm{O}(2)-\mathrm{C}(1)$ & $169.0(2)$ \\
$\mathrm{O}(2)-\mathrm{C}(1)-\mathrm{N}(1)$ & $115.6(3)$ & $\mathrm{O}(2)-\mathrm{C}(1)-\mathrm{N}(2)$ & $126.6(3)$ \\
$\mathrm{N}(1)-\mathrm{C}(1)-\mathrm{N}(2)$ & $117.8(3)$ & $\mathrm{C}(1)-\mathrm{N}(1)-\mathrm{C}(2)$ & $110.2(2)$ \\
$\mathrm{C}(1)-\mathrm{N}(1)-\mathrm{C}(4)$ & $110.8(2)$ & $\mathrm{C}(2)-\mathrm{N}(1)-\mathrm{C}(4)$ & $112.4(2)$ \\
$\mathrm{C}(1)-\mathrm{N}(2)-\mathrm{C}(6)$ & $127.5(3)$ & $\mathrm{C}(1)-\mathrm{N}(2)-\mathrm{C}(8)$ & $117.3(2)$ \\
$\mathrm{C}(6)-\mathrm{N}(2)-\mathrm{C}(8)$ & $115.1(2)$ & & \\
\hline
\end{tabular}

It should be notified that $\mathbf{4}$ provides the second crystallographic characterization of a N-protonated urea. ${ }^{11}$

\section{Coordination chemistry of $\mathrm{WOCl}_{4}$ with ureas.}

The reactions of $\mathrm{WOCl}_{4}$ with tmu and teu resulted in the formation of complicated mixtures of products. Protonated teu was recognized by IR analysis of the relevant reaction mixture (IR band at 1750 $\left.\mathrm{cm}^{-1}\right) .{ }^{11}$ The reaction with dpu afforded a mixture of $\mathrm{W}(\mathrm{V})$ species which could not be further identified; this fact suggests that electron interchange is somehow working in the course of the $\mathrm{WOCl}_{4} / \mathrm{dpu}$ interaction. The reaction of $\mathrm{WOCl}_{4}$ with $\mathrm{dmu}$ led to the isolation of the complex $\mathrm{WOCl}_{4}(\mathrm{dmu}), \mathbf{5}$, in $66 \%$ yield, Eqn. 5 .

$\mathrm{WOCl}_{4}+\mathrm{dmu} \rightarrow \mathrm{WOCl}_{4}(\mathrm{dmu})$

Crystals suitable for X-ray diffraction analysis were collected from a $\mathrm{CH}_{2} \mathrm{Cl}_{2} /$ hexane mixture by liquid diffusion.

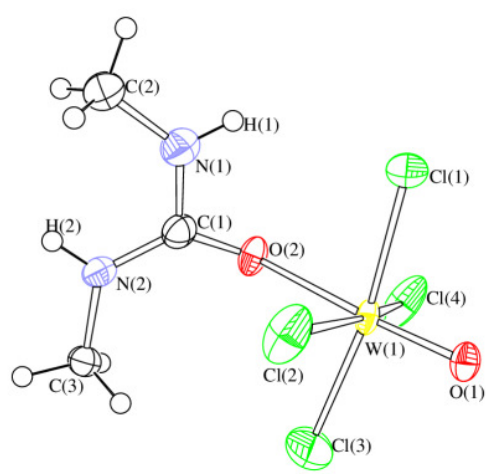

Figure 9. Molecular structure of 5, with key atoms labelled. Thermal ellipsoids are at the $50 \%$ probability level.

Table 5. Selected bond distances $(\AA)$ and angles $\left(^{\circ}\right)$ for $\mathbf{5}$.

\begin{tabular}{llll}
\hline $\mathrm{W}(1)-\mathrm{O}(1)$ & $1.693(11)$ & $\mathrm{W}(1)-\mathrm{O}(2)$ & $2.119(11)$ \\
$\mathrm{W}(1)-\mathrm{Cl}(1)$ & $2.327(9)$ & $\mathrm{W}(1)-\mathrm{Cl}(2)$ & $2.327(8)$ \\
$\mathrm{W}(1)-\mathrm{Cl}(3)$ & $2.266(10)$ & $\mathrm{W}(1)-\mathrm{Cl}(4)$ & $2.320(8)$ \\
$\mathrm{C}(1)-\mathrm{O}(2)$ & $1.349(16)$ & $\mathrm{C}(1)-\mathrm{N}(1)$ & $1.341(17)$ \\
$\mathrm{C}(1)-\mathrm{N}(2)$ & $1.354(16)$ & & \\
& & & \\
$\mathrm{O}(1)-\mathrm{W}(1)-\mathrm{O}(2)$ & $175.8(6)$ & $\mathrm{Cl}(1)-\mathrm{W}(1)-\mathrm{Cl}(3)$ & $171.2(4)$ \\
$\mathrm{Cl}(2)-\mathrm{W}(1)-\mathrm{Cl}(4)$ & $166.2(3)$ & $\mathrm{W}(1)-\mathrm{O}(2)-\mathrm{C}(1)$ & $128.2(13)$ \\
$\mathrm{O}(2)-\mathrm{C}(1)-\mathrm{N}(1)$ & $114.1(15)$ & $\mathrm{O}(2)-\mathrm{C}(1)-\mathrm{N}(2)$ & $129.5(18)$ \\
$\mathrm{N}(1)-\mathrm{C}(1)-\mathrm{N}(2)$ & $115.7(17)$ & $\mathrm{C}(1)-\mathrm{N}(1)-\mathrm{C}(2)$ & $128(2)$ \\
$\mathrm{C}(1)-\mathrm{N}(2)-\mathrm{C}(3)$ & $125.1(18)$ & & \\
\hline
\end{tabular}

Complex 5 displays a distorted octahedral geometry around W(1) with the oxide and dmu ligands in relative trans position, as previously found in the other $\mathrm{WOCl}_{4} \mathrm{~L}$ complexes crystallographically characterized. ${ }^{19,20,40}$ The $\mathrm{W}=\mathrm{O}$ distance $[\mathrm{W}(1)$ $\mathrm{O}(1) 1.693(11) \AA]$ in the W(VI) complex 5 is similar to that detected in the $\mathrm{W}(\mathrm{V})$ complex $4[\mathrm{~W}(1)-\mathrm{O}(1) 1.681(2) \AA]$. Conversely, the $\mathrm{W}-\mathrm{O}$ and $\mathrm{W}-\mathrm{Cl}$ contacts are longer in 4 [W(1)-O(2) 2.292(2) $\AA$; $\mathrm{W}-\mathrm{Cl}$ 2.3584(8)-2.4126(7) $\AA$ ] compared to 5 [W(1)-O(2) 2.119(11) $\AA ;$ W-Cl 2.260(10)-2.327(9) $\AA$ ]. Following the classification of Jeffrey, ${ }^{41}$ the $\mathrm{N}(1)-\mathrm{H}(1)$ group is involved in a weak intra-molecular H-bond with $\mathrm{Cl}(1) \quad[\mathrm{N}(1)-\mathrm{H}(1) \quad 0.88 \AA, \mathrm{H}(1) \cdots \mathrm{Cl}(1) 2.70 \AA$, $\left.\mathrm{N}(1) \cdots \mathrm{Cl}(1) 3.39(2) \AA, \quad<\mathrm{N}(1) \mathrm{H}(1) \mathrm{Cl}(1) 136.6^{\circ}\right]$, whereas $\mathrm{N}(2)$ $\mathrm{H}(2)$ forms an inter-molecular $\mathrm{H}-$ bond with the $\mathrm{Cl}(1) \# 1$ atom of an adjacent molecule $[\mathrm{N}(1)-\mathrm{H}(1) \quad 0.88 \AA \AA \mathrm{H}(1) \cdots \mathrm{Cl}(1) \# 12.82 \AA$, $\mathrm{N}(1) \cdots \mathrm{Cl}(1) \# 13.522(19) \AA,<\mathrm{N}(1) \mathrm{H}(1) \mathrm{Cl}(1) \# 1 \quad 137.4^{\circ}$, Symmetry transformation \#1: $\mathrm{x}+1 / 2,-\mathrm{y}+3 / 2, \mathrm{z}-1 / 2]$.

\section{Conclusions}

In contrast to other carbonyl compounds, alkyl and phenyl ureas do not undergo chlorination of the $[\mathrm{C}=\mathrm{O}]$ moiety when allowed to contact with $\mathrm{WCl}_{6}$. Instead, electron interchange is working driven by the oxidative power of the $\mathrm{W}(\mathrm{VI})$ centre, and leading to the formation of $\mathrm{W}(\mathrm{V})$ chloride salts of O-protonated ureas. This electron interchange may trigger the activation of $\mathrm{C}-\mathrm{H}$ and/or $\mathrm{N}-\mathrm{H}$ bonds, as unusual $H^{+}$sources. Evidences for a $\mathrm{N}-\mathrm{H}$ activation pathway, including the possible involvement of the solvent (dichloromethane), have been collected for the $\mathrm{WCl}_{6} / \mathrm{dpu}$ system by NMR spectroscopy and DFT calculations. It seems that the introduction of an oxide ligand within the $\mathrm{W}(\mathrm{VI})$ chloride (compare $\mathrm{WOCl}_{4}$ to $\mathrm{WCl}_{6}$ ) somehow inhibits the urea oxidation. The $\left[\mathrm{WCl}_{6}\right]^{-}$ protonated urea salts are generally unstable at high temperature, resulting in $\mathrm{HCl}$ release and providing the access to rare examples of crystallographically characterized $\mathrm{WCl}_{5}$ coordination complexes.

\section{Experimental}

\section{General}


Warning: all the metal products reported in this paper are highly moisture-sensitive, thus rigorously anhydrous conditions were required for the reaction and crystallization procedures. The reaction vessels were oven dried at $140^{\circ} \mathrm{C}$ prior to use, evacuated $\left(10^{-2}\right.$ $\mathrm{mmHg}$ ) and then filled with argon. $\mathrm{WCl}_{6}$ was purchased from Strem (99.9\% purity) and stored in sealed glass tubes under argon atmosphere. $\mathrm{WOCl}_{4}{ }^{42}$ and $\mathrm{WCl}_{5}{ }^{38}$ were prepared according to the literature. Once isolated, the metal products were conserved in sealed glass tubes under argon. Tetramethylurea (tmu), tetraethylurea (teu), 1,3-diphenylurea (dpu) and 1,3-dimethylurea $(\mathrm{dmu})$ were purchased from Alfa Aesar and stored under argon atmosphere as received. Solvents (Sigma Aldrich) were distilled from appropriate drying agents before use. Infrared spectra were recorded at $298 \mathrm{~K}$ on a FT IR-Perkin Elmer Spectrometer, equipped with a UATR sampling accessory. Magnetic susceptibilities (reported per W atom) were measured at $298 \mathrm{~K}$ on solid samples with a Magway MSB Mk1 magnetic susceptibility balance (Sherwood Scientific Ltd.). Diamagnetic corrections were introduced according to König. ${ }^{43}$ NMR spectra were recorded at $298 \mathrm{~K}$ (unless otherwise stated) on a Bruker Avance II DRX400 instrument equipped with a BBFO broadband probe. The chemical shifts for ${ }^{1} \mathrm{H}$ and ${ }^{13} \mathrm{C}$ were referenced to the non-deuterated aliquot of the solvent. The spectra were fully assigned via ${ }^{1} \mathrm{H},{ }^{13} \mathrm{C}$ correlation measured through $g_{s}$-HSQC and gsHMBC experiments. ${ }^{44}$ Carbon, hydrogen and nitrogen analyses were performed on a Carlo Erba mod. 1106 instrument. The chloride content was determined by the Mohr method ${ }^{45}$ on solutions prepared by dissolution of the solid in aqueous $\mathrm{KOH}$ at boiling temperature, followed by cooling to room temperature and addition of $\mathrm{HNO}_{3}$ up to neutralization.

\section{Reactions of $\mathrm{WCl}_{6}$ with ureas (1:2 molar ratio).}

Synthesis and isolation of $\left[(\mathrm{O}-\mathrm{H}-\mathrm{O})-(\mathrm{tmu})_{2}(\mu-\mathrm{H})\right]\left[\mathrm{WCl}_{6}\right], 1 \mathrm{a}$, and $\left[(\boldsymbol{O}-\mathrm{H}-\mathrm{O})-(\mathrm{dpu})_{2}(\mu-\mathrm{H})\right]\left[\mathrm{WCl}_{\mathbf{6}}\right], \mathbf{1 b}$. The synthesis of $\mathbf{1 a}$ is described in detail, $\mathbf{1 b}$ being prepared by analogous procedure. $\mathrm{WCl}_{6}(0.320 \mathrm{~g}, 0.806 \mathrm{mmol})$, suspended in $\mathrm{CH}_{2} \mathrm{Cl}_{2}(15 \mathrm{~mL})$, was treated with tmu $(0.204 \mathrm{~mL}, 1.70 \mathrm{mmol})$. The mixture was stirred at room temperature for 18 hours. The resulting red solution was concentrated to $c a .5 \mathrm{~mL}$, layered with hexane and set aside at -30 ${ }^{\circ} \mathrm{C}$. X-ray quality crystals were recovered after one week. Yield: $0.203 \mathrm{~g}, 40 \%$. Anal. Calcd for $\mathrm{C}_{10} \mathrm{H}_{25} \mathrm{Cl}_{6} \mathrm{~N}_{4} \mathrm{O}_{2} \mathrm{~W}: \mathrm{C}, 19.07 ; \mathrm{H}, 4.00$; $\mathrm{N}, 8.89 ; \mathrm{Cl}, 33.77$. Found: C, 19.17; H, 4.11; N, 8.77; Cl, 33.42. IR (solid state): $1688 \mathrm{~s}\left(v_{\mathrm{NCN}}+\delta_{\mathrm{OH}}\right), 1632 \mathrm{vs}\left(v_{\mathrm{C}=\mathrm{O}}+\delta_{\mathrm{OH}}\right), 1593 \mathrm{~m}$ $\left(v_{\mathrm{CN}}+v_{\mathrm{C}=0}\right) \mathrm{cm}^{-1}$. Magnetic measurement: $\chi_{\mathrm{M}}{ }^{\text {corr }}=3.72 \times 10^{-4}$ cgsu, $\mu_{\text {eff }}=0.95 \mathrm{BM}$.

$\left[(\boldsymbol{O}-\mathbf{H}-\mathrm{O})-(\mathrm{dpu})_{\mathbf{2}}(\boldsymbol{\mu}-\mathbf{H})\right]\left[\mathrm{WCl}_{\mathbf{6}}\right], \mathbf{1 b}$. Green-brown solid, from $\mathrm{WCl}_{6}$ $(0.310 \mathrm{~g}, 0.781 \mathrm{mmol})$ and dpu $(0.335 \mathrm{~g}, 1.58 \mathrm{mmol})$. Yield: 0.417 g, 65\%. Anal. Calcd for $\mathrm{C}_{26} \mathrm{H}_{25} \mathrm{Cl}_{6} \mathrm{~N}_{4} \mathrm{O}_{2} \mathrm{~W}: \mathrm{C}, 37.99 ; \mathrm{H}, 3.07 ; \mathrm{N}$, 6.82; Cl, 25.88. Found: C, 38.08; H, 3.17; N, 6.69; Cl, 25.72. IR (solid state): $3329 \mathrm{~m}-\mathrm{br}\left(v_{\mathrm{NH}}\right), 3042 \mathrm{w}, 2964 \mathrm{w}, 1628 \mathrm{~s}\left(\mathrm{v}_{\mathrm{C}=\mathrm{O}}+\delta_{\mathrm{NH}}\right)$, $1594 \mathrm{~s}$ and $1585 \mathrm{~s}\left(v_{\mathrm{CN}}+\delta_{\mathrm{NH}}\right), 1547 \mathrm{vs}\left(v_{\mathrm{CN}}+\delta_{\mathrm{NH}}+\delta_{\mathrm{OH}}\right)$, $1494 \mathrm{vs}, 1447 \mathrm{~m}, 1404 \mathrm{w}, 1362 \mathrm{w}, 1316 \mathrm{w}, 1260 \mathrm{w}-\mathrm{m}, 1226 \mathrm{w}-\mathrm{m}$, $1074 \mathrm{w}, 1047 \mathrm{w}, 1025 \mathrm{w}, 981 \mathrm{~m}, 891 \mathrm{w}, 803 \mathrm{~m}, 751 \mathrm{vs}, 689 \mathrm{vs} \mathrm{cm}{ }^{-1} .{ }^{1} \mathrm{H}$ NMR $\left(\mathrm{CDCl}_{3}\right): \delta=8.12,7.71,7.54,7.44,7.34$ (br) ppm. ${ }^{13} \mathrm{C}\left\{{ }^{1} \mathrm{H}\right\}$ NMR $\left(\mathrm{CDCl}_{3}\right): \delta=158.0$ (CO), 134.2 (ipso-Ph), 130.3, 127.8, $125.7(\mathrm{Ph}) \mathrm{ppm}$. Magnetic measurement: $\chi_{\mathrm{M}}{ }^{\text {corr }}=3.42 \times 10^{-4} \mathrm{cgsu}$, $\mu_{\text {eff }}=0.91 \mathrm{BM}$.

IR characterization of $[\mathbf{t m u H}]^{+}$. The dichloromethane reaction solution obtained from $\mathrm{WCl}_{6}(0.850 \mathrm{mmol})$ and tmu $(1.80 \mathrm{mmol})$ was eliminated of the volatile materials, and the residue was allowed to contact with hexane $(50 \mathrm{~mL})$ for 24 hours. Then the liquors were removed, and the red solid was dried in vacuo. Subsequent IR analysis allowed to identify $\left[\left(\mathrm{Me}_{2} \mathrm{~N}\right)_{2} \mathrm{COH}\right]^{+}$(IR absorptions at 3329 and $\left.1661 \mathrm{~cm}^{-1}\right),{ }^{11}$ in admixture with 1a (major).

\section{Reactions of $\mathrm{WCl}_{6}$ with ureas (1:1 molar ratio).}

Synthesis and isolation of $[\mathrm{dpu}(O-\mathrm{O})]\left[\mathrm{WCl}_{\mathbf{6}}\right], 2$. A suspension of $\mathrm{WCl}_{6}(0.310 \mathrm{~g}, 0.781 \mathrm{mmol})$ in $\mathrm{CH}_{2} \mathrm{Cl}_{2}(15 \mathrm{~mL})$ was treated with dpu $(0.165 \mathrm{~g}, 0.777 \mathrm{mmol})$. The mixture was stirred for 18 hours at room temperature. The final dark-red solution was concentrated to ca. $5 \mathrm{~mL}$ and added of hexane $(50 \mathrm{~mL})$. Thus precipitation occurred of a red-brown microcrystalline solid which was dried in vacuo. Yield $0.324 \mathrm{~g}, 68 \%$. Anal. Calcd for $\mathrm{C}_{13} \mathrm{H}_{13} \mathrm{Cl}_{6} \mathrm{~N}_{2} \mathrm{OW}$ : C, 25.60; H, 2.15; N, 4.59; Cl, 34.88. Found: C, 25.82; H, 2.07; N, 4.71; Cl, 34.65. IR (solid state): 3305m-br $\left(v_{\mathrm{NH}}\right), 3053 \mathrm{w}, 2962 \mathrm{w}$, $1609 \mathrm{~s}\left(\mathrm{v}_{\mathrm{NCN}}+\delta_{\mathrm{OH}}\right), 1578 \mathrm{~s}, 1549 \mathrm{vs}, 1492 \mathrm{~m}-\mathrm{s}, 1456 \mathrm{~m}, 1398 \mathrm{~m}$, $1351 \mathrm{~m}, 1309 \mathrm{w}-\mathrm{m}, 1216 \mathrm{w}, 1048 \mathrm{~m}, 1023 \mathrm{~ms}, 991 \mathrm{~m}, 921 \mathrm{w}, 819 \mathrm{~m}$, $751 \mathrm{~s}, 732 \mathrm{~s}, 692 \mathrm{vs} \mathrm{cm}{ }^{-1} .{ }^{1} \mathrm{H} \mathrm{NMR}\left(\mathrm{CDCl}_{3}\right): \delta=10.11(\mathrm{~s}-\mathrm{br}, 1 \mathrm{H}$, $\mathrm{OH})$, 8.07-7.03 (m-br, $12 \mathrm{H}, \mathrm{Ph}$ and $\mathrm{NH}) \mathrm{ppm} .{ }^{13} \mathrm{C}\left\{{ }^{1} \mathrm{H}\right\} \mathrm{NMR}$ $\left(\mathrm{CDCl}_{3}\right): \delta=214.1(\mathrm{C}=\mathrm{O}), 138.2(\mathrm{ipso}-\mathrm{Ph}), 134.2-126.2(\mathrm{Ph}) \mathrm{ppm}$. Magnetic measurement: $\chi_{\mathrm{M}}{ }^{\text {corr }}=3.06 \times 10^{-4}$ cgsu, $\mu_{\text {eff }}=0.86 \mathrm{BM}$.

Synthesis and isolation of $\mathbf{W C l}_{5}(\mathbf{d m u}), 3 \mathrm{a}$. The reaction of $\mathrm{WCl}_{6}$ $(0.400 \mathrm{~g}, 1.01 \mathrm{mmol})$ with dmu $(0.088 \mathrm{~g}, 0.999 \mathrm{mmol})$ was carried out by a procedure analogous to that described for the synthesis of 2. Green-brown crystals suitable for X-ray analysis were collected from the reaction solution layered with hexane and set aside at -30 ${ }^{\circ} \mathrm{C}$. Yield $0.204 \mathrm{~g}, 45 \%$. Anal. Calcd for $\mathrm{C}_{3} \mathrm{H}_{8} \mathrm{Cl}_{5} \mathrm{~N}_{2} \mathrm{OW}$ : C, 8.02; H, 1.80; N, 6.24; Cl, 39.46. Found: C, 7.93; H, 1.86; N, 6.17; Cl, 39.15. IR (solid state): $3305 \mathrm{~m}-\mathrm{br}, 3053 \mathrm{w}, 2962 \mathrm{w}, 1609 \mathrm{~s}\left(\mathrm{v}_{\mathrm{NCN}}+\right.$ $\left.\delta_{\mathrm{NH}}\right), 1578 \mathrm{~s}\left(\mathrm{v}_{\mathrm{C}=\mathrm{O}}+\delta_{\mathrm{NH}}\right), 1549 \mathrm{vs}, 1492 \mathrm{~m}-\mathrm{s}, 1456 \mathrm{~m}, 1398 \mathrm{~m}$, $1351 \mathrm{~m}, 1309 \mathrm{w}-\mathrm{m}, 1216 \mathrm{w}, 1048 \mathrm{~m}, 102 \mathrm{~ms}, 991 \mathrm{~m}, 921 \mathrm{w}, 819 \mathrm{~m}$, $751 \mathrm{~s}, 732 \mathrm{~s}, 692 \mathrm{vs} \mathrm{cm}^{-1} .{ }^{1} \mathrm{H}$ NMR $\left(\mathrm{CD}_{3} \mathrm{CN}\right): \delta=6.2(\mathrm{br}, \mathrm{NH}), 2.87$ (s-br, Me) ppm. Magnetic measurement: $\chi_{\mathrm{M}}{ }^{\text {corr }}=3.30 \times 10^{-4} \mathrm{cgsu}$, $\mu_{\text {eff }}=0.89 \mathrm{BM}$.

IR characterization of $[\mathbf{d m u H}]^{+}$. The dichloromethane reaction solution obtained from $\mathrm{WCl}_{6}(0.650 \mathrm{mmol})$ and $\mathrm{dmu}(0.65 \mathrm{mmol})$ was eliminated of the volatile materials, and the residue was allowed to contact with hexane $(50 \mathrm{~mL})$ for 24 hours. Then the liquors were removed, and the red solid was dried in vacuo. Subsequent IR analysis allowed to identify $\left[(\mathrm{MeNH})_{2} \mathrm{COH}\right]^{+}$, in admixture with 3a (major). IR (solid state): $1660\left(v_{\mathrm{NCN}}+\delta_{\mathrm{OH}}\right)$ $\mathrm{cm}^{-1}$.

Analysis of the 1:1 $\mathrm{WCl}_{6} / \mathrm{dpu}$ reaction mixture. A mixture of $\mathrm{WCl}_{6}(0.80 \mathrm{mmol}), \mathrm{CH}_{2} \mathrm{Cl}_{2}(15 \mathrm{~mL})$ and dpu $(0.80 \mathrm{mmol})$ was stirred at room temperature for $48 \mathrm{~h}$. The resulting mixture was dried in vacuo thus affording a brown solid. IR (solid state): $3317 \mathrm{~m}-\mathrm{br}, 3040 \mathrm{w}, 2963 \mathrm{w}, 1621 \mathrm{~m}-\mathrm{sh}, 1611 \mathrm{~s}-\mathrm{br}, 1593 \mathrm{~m}-\mathrm{s}, 1579 \mathrm{~s}$, $1562 \mathrm{~s}, 1550 \mathrm{vs}-\mathrm{br}, 1540 \mathrm{~s}, 1495 \mathrm{~m}-\mathrm{s}, 1455 \mathrm{~m}, 1440 \mathrm{~m}, 1397 \mathrm{~m}$, $1354 \mathrm{~m}, 1309 \mathrm{w}-\mathrm{m}, 1260 \mathrm{~m}, 1216 \mathrm{w}, 1048 \mathrm{~m}, 1023 \mathrm{~ms}, 987 \mathrm{~m}, 921 \mathrm{w}$, $803 \mathrm{~m}, 750 \mathrm{~s}, 729 \mathrm{~m}, 691 \mathrm{vs} \mathrm{cm}{ }^{-1}$. Magnetic measurement: $\chi_{\mathrm{M}}{ }^{\text {corr }}=$ $3.61 \times 10^{-4} \mathrm{cgsu}, \mu_{e f f}=0.96 \mathrm{BM}$. The solid residue was treated with $\mathrm{CDCl}_{3}(1.5 \mathrm{~mL})$ and a large excess of $\mathrm{H}_{2} \mathrm{O}$ (ca. $0.2 \mathrm{~mL}$ ). The mixture was stirred at room temperature in contact with air for 48 h. Hence, the organic phase was separated and analyzed by NMR ${ }^{1} \mathrm{H} \mathrm{NMR}\left(\mathrm{CDCl}_{3}\right): \delta=8.4$ (br, NH dpu), $5.84(\mathrm{br}) ; 7.53-7.08,6.98$ $6.84(\mathrm{~m}, \mathrm{Ph}) ; 2.87,2.07,1.71(\mathrm{~s}) \mathrm{ppm} .{ }^{13} \mathrm{C}\left\{{ }^{1} \mathrm{H}\right\} \mathrm{NMR}\left(\mathrm{CDCl}_{3}\right): \delta=$ $154.0(\mathrm{C}=\mathrm{O}), 152.8(\mathrm{C}=\mathrm{O}, \mathrm{dpu}), 138.9(\mathrm{dpu}), 137.5,129.9,129.4$ (minor), 129.2 (minor), $128.8(\mathrm{dpu}), 126.4,124.5,123.2,122.8$ (dpu), 120.8, 119.8 (dpu), 38.8, 34.0, 27.4, 23.0 ppm. After removal of the volatiles, the organic substrate was analyzed also by IR spectroscopy. IR (solid state): 3481w, 3284m-br, 3034w, 2961w, 1646s-br (dpu), 1593s (dpu), 1583s, 1539vs, 1496vs, $1440 \mathrm{~s}, 1360 \mathrm{w}, 1312 \mathrm{~m}, 1294 \mathrm{~m}, 1258 \mathrm{~s}, 1230 \mathrm{~s}, 1175 \mathrm{~s}, 1155 \mathrm{w}$, $1070 \mathrm{~m}, 1051 \mathrm{~m}, 1024 \mathrm{~m}-\mathrm{s}, 893 \mathrm{~m}, 863 \mathrm{w}-\mathrm{m}, 799 \mathrm{~s}, 749 \mathrm{vs}, 691 \mathrm{vs}$ $\mathrm{cm}^{-1}$.

Synthesis and isolation of $\mathrm{WCl}_{\mathbf{5}}(\mathrm{tmu}), \mathbf{3 b}$, and $\mathrm{WCl}_{\mathbf{5}}(\mathrm{teu}), \mathbf{3 c}$. A mixture of $\mathrm{WCl}_{6}(0.350 \mathrm{~g}, 0.882 \mathrm{mmol})$ and tmu $(0.110 \mathrm{~mL}, 0.917$ $\mathrm{mmol})$ in toluene $(20 \mathrm{~mL})$ was heated at reflux temperature for 5 days. The final dark-brown solution was filtered and then eliminated of the volatile materials. The residue was washed with cyclohexane $(2 \times 30 \mathrm{~mL})$ and dried in vacuo. Yield $0.135 \mathrm{~g}, 32 \%$. 
Crystals of 3b suitable for X-ray analysis were obtained in admixture with an oil of the same colour from a 1,2-dichlorethane solution layered with heptane and settled aside at $-30{ }^{\circ} \mathrm{C}$. Anal. Calcd for $\mathrm{C}_{5} \mathrm{H}_{12} \mathrm{Cl}_{5} \mathrm{~N}_{2} \mathrm{OW}$ : C, 12.58; $\mathrm{H}, 2.53 ; \mathrm{N}, 5.87 ; \mathrm{Cl}, 37.14$. Found: $\mathrm{C}, 12.45 ; \mathrm{H}, 2.69 ; \mathrm{N}, 5.60 ; \mathrm{Cl}, 36.68$. IR (solid state): $3100 \mathrm{w}, 2944 \mathrm{w}, 1638 \mathrm{~s}\left(\mathrm{v}_{\mathrm{NCN}}\right), 1514 \mathrm{~s}\left(\mathrm{v}_{\mathrm{C}=\mathrm{O}}+\delta_{\mathrm{NH}}\right), 1463 \mathrm{~s}, 1398 \mathrm{vs}$, $1278 \mathrm{vs}\left(v_{\mathrm{CO}}\right), 1201 \mathrm{~s}, 1059 \mathrm{~m}, 889 \mathrm{~m}, 802 \mathrm{~s}, 781 \mathrm{vs} \mathrm{cm}^{-1}$. Magnetic measurement: $\chi_{\mathrm{M}}{ }^{\text {corr }}=3.30 \times 10^{-4} \mathrm{cgsu}, \mu_{\text {eff }}=0.89 \mathrm{BM}$.

$\mathbf{W C l}_{5}(\mathbf{t e u}), 3 \mathrm{c}$. Compound $3 \mathbf{c}$ was prepared by allowing $\mathrm{WCl}_{6}$ $(0.310 \mathrm{~g}, 0.781 \mathrm{mmol})$ to react with teu $(0.150 \mathrm{~mL}, 0.790 \mathrm{mmol})$ in 1,2-dichloroethane at reflux temperature for $20 \mathrm{~h}$. Then the solvent was removed, and the residue was extracted with toluene $(3 \times 20$ $\mathrm{mL}$ ). The resulting toluene solution of $\mathbf{3 c}$ was dried in vacuo thus affording a dark-red solid. Yield: $0.162 \mathrm{~g}, 39 \%$. Anal. Calcd for $\mathrm{C}_{9} \mathrm{H}_{20} \mathrm{Cl}_{5} \mathrm{~N}_{2} \mathrm{OW}$ : C, 20.27; $\mathrm{H}, 3.78 ; \mathrm{N}, 5.25 ; \mathrm{Cl}, 33.23$. Found: $\mathrm{C}$, 20.15; H, 3.86; N, 5.16; Cl, 33.01. IR (solid state): $1636 \mathrm{~s}\left(v_{\mathrm{NCN}}\right)$, $1603 \mathrm{~s}\left(v_{\mathrm{C}=\mathrm{O}}\right) \mathrm{cm}^{-1}$. Magnetic measurement: $\chi_{\mathrm{M}}{ }^{\text {corr }}=3.66 \times 10^{-4}$ cgsu, $\mu_{\text {eff }}=0.94 \mathrm{BM}$.

Reactions of $\mathrm{WCl}_{5}$ with ureas. Isolation of $\mathrm{WOCl}_{4}(\mathrm{teuH}), 4$. General procedure: a mixture of $\mathrm{WCl}_{5}(0.60 \mathrm{mmol})$ and $\mathrm{CH}_{2} \mathrm{Cl}_{2}$ $(10 \mathrm{~mL})$ was treated with the appropriate urea $(0.60 \mathrm{mmol})$. The mixture was stirred at room temperature for $18 \mathrm{~h}$. Then, pentane $(50 \mathrm{~mL})$ was added, and the precipitate was separated and dried in vacuo. Compounds $\mathrm{WCl}_{5}$ (urea), 3a-c, were obtained in $40-50 \%$ yields, and identified by elemental analysis and IR spectroscopy. Few crystals of $\mathbf{4}$ suitable for X-ray analysis were collected from a dichloromethane solution obtained from $\mathrm{WCl}_{5} /$ teu, layered with hexane and stored at $-30{ }^{\circ} \mathrm{C}$ for two weeks. Anal. Calcd for $\mathrm{C}_{9} \mathrm{H}_{21} \mathrm{Cl}_{4} \mathrm{~N}_{2} \mathrm{O}_{2} \mathrm{~W}$ : C, 20.99; $\mathrm{H}, 4.11 ; \mathrm{N}, 5.44 ; \mathrm{Cl}, 27.54$. Found: $\mathrm{C}$, 21.05; H, 4.02; N, 5.59; Cl, 27.39. IR (solid state): $v=3101 \mathrm{w}-\mathrm{m}$ $\left(v_{\mathrm{NH}}\right), 1740 \mathrm{~s}\left(v_{\mathrm{CO}}+v_{\mathrm{CN}}+\delta_{\mathrm{NH}}\right), 980 \mathrm{~m}\left(v_{\mathrm{W}=\mathrm{O}}\right) \mathrm{cm}^{-1}$. Magnetic measurement: $\chi_{\mathrm{M}}{ }^{\text {corr }}=3.31 \times 10^{-4}$ cgsu, $\mu_{\text {eff }}=0.89 \mathrm{BM}$.

\section{Reactions of $\mathrm{WOCl}_{4}$ with ureas.}

Synthesis and isolation of $\mathrm{WOCl}_{4}(\mathbf{d m u})$, 5. A suspension of $\mathrm{WOCl}_{4}(0.250 \mathrm{~g}, 0.732 \mathrm{mmol})$ in $\mathrm{CH}_{2} \mathrm{Cl}_{2}(15 \mathrm{~mL})$ was treated with dmu $(0.065 \mathrm{~g}, 0.738 \mathrm{mmol})$. The resulting mixture was stirred at room temperature for $18 \mathrm{~h}$, thus it was eliminated of the volatile materials. The residue was washed with hexane $(2 \times 20 \mathrm{~mL})$ and dried in vacuo. The product was recovered as an orange solid. Yield $0.207 \mathrm{~g}, 66 \%$. Anal. Calcd for $\mathrm{C}_{3} \mathrm{H}_{8} \mathrm{Cl}_{4} \mathrm{~N}_{2} \mathrm{O}_{2} \mathrm{~W}: \mathrm{C}, 8.38 ; \mathrm{H}$, $1.88 ; \mathrm{N}, 6.52 ; \mathrm{Cl}, 33.00$. Found: $\mathrm{C}, 8.25 ; \mathrm{H}, 1.90 ; \mathrm{N}, 6.51 ; \mathrm{Cl}$, 32.84. IR (solid state): $v=3425 \mathrm{w}, 3404 \mathrm{~m}\left(v_{\mathrm{N}-\mathrm{H}}\right), 2945 \mathrm{w}, 1613 \mathrm{~s}-\mathrm{sh}$ and $1585 \mathrm{vs}-\mathrm{br}\left(\mathrm{v}_{\mathrm{CO}}+\delta_{\mathrm{NH}}+\mathrm{v}_{\mathrm{NCN}}\right), 1474 \mathrm{w}, 1453 \mathrm{w}, 1388 \mathrm{~s}, 1352 \mathrm{~m}$, $1165 \mathrm{~m}, 1150 \mathrm{w}-\mathrm{m}, 1040 \mathrm{w}, 981 \mathrm{vs}\left(\mathrm{v}_{\mathrm{W}=\mathrm{O}}\right), 898 \mathrm{~m}, 859 \mathrm{w}-\mathrm{br}, 811 \mathrm{w}-\mathrm{br}$, $742 \mathrm{~m} \mathrm{~cm}^{-1} .{ }^{1} \mathrm{H}$ NMR $\left(\mathrm{CD}_{2} \mathrm{Cl}_{2}\right): \delta=6.06(\mathrm{br}, 1 \mathrm{H}, \mathrm{NH}), 2.99(\mathrm{~s}, 3$ $\mathrm{H}, \mathrm{Me}) \mathrm{ppm} .{ }^{13} \mathrm{C}$ NMR $\left(\mathrm{CD}_{2} \mathrm{Cl}_{2}\right): \delta=161.5(\mathrm{C}=\mathrm{O}), 28.3(\mathrm{Me})$ ppm.

Reaction of $\mathrm{WOCl}_{4}$ with dpu. The reaction of $\mathrm{WOCl}_{4}(0.320 \mathrm{~g}$, $0.937 \mathrm{mmol})$ with $\mathrm{O}=\mathrm{C}(\mathrm{NHPh})_{2}(0.200 \mathrm{~g}, 0.942 \mathrm{mmol})$ was performed by a procedure analogous to that described for the synthesis of 5. A dark-red microcrystalline solid was isolated. Yield 0.286 g. IR (solid state): $v=3366 \mathrm{w}-\mathrm{m}\left(v_{\mathrm{N}-\mathrm{H}}\right), 1610 \mathrm{~s}, 1593 \mathrm{~s}$, $1583 \mathrm{~s}, 1552 \mathrm{vs}, 1494 \mathrm{~m}, 1454 \mathrm{~m}, 1400 \mathrm{w}-\mathrm{m}, 1360 \mathrm{~m}, 1308 \mathrm{w}, 1221 \mathrm{w}$, $1051 \mathrm{w}, 1026 \mathrm{w}, 980 \mathrm{~s}\left(v_{\mathrm{W}=\mathrm{O}}\right), 885 \mathrm{w}, 853 \mathrm{w}, 746 \mathrm{~s}, 730 \mathrm{~m}, 699 \mathrm{~s} \mathrm{~cm}^{-1}$. Magnetic measurement: $\chi_{\mathrm{M}}{ }^{\text {corr }}=3.53 \times 10^{-4} \mathrm{cgsu}, \mu_{\text {eff }}=0.92 \mathrm{BM}$. ${ }^{1} \mathrm{H}$ NMR $\left(\mathrm{CD}_{2} \mathrm{Cl}_{2}\right): \delta=7.9-7.3(\mathrm{~m}-\mathrm{br}, \mathrm{NH}$ and $\mathrm{Ph}) \mathrm{ppm} .{ }^{13} \mathrm{C} \mathrm{NMR}$ $\left(\mathrm{CD}_{2} \mathrm{Cl}_{2}\right): \delta=157.5(\mathrm{C}=\mathrm{O}), 135.3,129.5,126.5,124.2(\mathrm{Ph}) \mathrm{ppm}$.

X-ray Crystallography. Crystal data and collection details for 1a, $\mathbf{1 b}, \mathbf{3 a}, \mathbf{3 b}, \mathbf{4}$ and $\mathbf{5}$ are reported in Table 6 . The diffraction experiments were carried out on a Bruker APEX II diffractometer equipped with a CCD detector using $M o-K \alpha$ radiation. Data were corrected for Lorentz polarization and absorption effects (empirical absorption correction SADABS) ${ }^{46}$ Structures were solved by direct methods and refined by full-matrix least-squares based on all data using $F^{2}{ }^{47} \mathrm{C}$-bonded hydrogen atoms were fixed at calculated positions and refined by a riding model, whereas $\mathrm{O}$ and $\mathrm{N}$ bonded hydrogens have been located in the Fourier map. $\mathrm{N}-\mathrm{H}$ and $\mathrm{O}-\mathrm{H}$ distances have been restrained to 0.89 and $0.87 \AA$, respectively (s.u. 0.01). The $\left[\mathrm{WCl}_{6}\right]^{-}$anion in 1a is located on an inversion centre at $\mathrm{W}$. The $\left[(\mathrm{tmu})_{2} \mathrm{H}\right]^{+}$cation in $\mathbf{1 a}$ is located close to an inversion centre with $H(1)$ split over two equally populated symmetry equivalent positions (occupancy factor 0.5 ); therefore, only one tmu molecule and $\mathrm{H}(1)$ are independent, whereas the rest of the cation is generated by inversion. Similar $U$ restraints [SIMU line in SHELXL; s.u. 0.01] were applied to the organic molecules of $\mathbf{1 b}$ and 3a. The crystals of $\mathbf{3 a}$ are racemically twinned with refined absolute structure parameter $0.035(13)$. The crystals of 3a contain three independent molecules with very similar geometries and structural parameters. The crystals of $\mathbf{5}$ are pseudomerohedrally twinned with twin matrix $\begin{array}{lllllllll}1 & 0 & 0 & 0 & -1 & 0 & 0 & 0 & -1\end{array}$ and refined batch factor 0.566(9). Because of this twinning, several restraints have been applied during refinement. In particular, all the atoms were restrained to have similar $U$ parameters [SIMU command in SHELXL, s.u. 0.01]. Bond distances were restrained as follows [DFIX command in SHELXL, s.u. 0.02]: $\mathrm{C}(1)-\mathrm{O}(2)$ $1.25 \AA, \mathrm{C}(1)-\mathrm{N}(1)$ and $\mathrm{C}(1)-\mathrm{N}(2) 1.33 \AA, \mathrm{N}(1)-\mathrm{C}(2)$ and $\mathrm{N}(2)-\mathrm{C}(3)$ $1.45 \AA$. All the largest peaks and electron holes present in these structures are located close to the strongly absorbing $\mathrm{W}$ atoms and are series termination errors which are common with heavy atoms such as W.

\section{Insert Table 6 about here}

Computational studies. The computational geometry optimizations were carried out without symmetry constrains, using the range-separated DFT functional $\omega \mathrm{B} 97 \mathrm{X}^{48}$ in combination with a polarized basis set composed by the $6-31 \mathrm{G}(\mathrm{d}, \mathrm{p})$ set on the light atoms and the ECP-based LANL2TZ(f) on the metal centre. ${ }^{49}$ The choice of the DFT functional was based on literature outcomes, in particular the comparative work of Jensen and co-workers concerning DFT studies on transition metal complexes. ${ }^{48}$ The "unrestricted" formalism was applied for compounds with unpaired electrons, and the lack of spin contamination was verified by comparing the computed $\left\langle\mathrm{S}^{2}\right\rangle$ values with the theoretical ones. The stationary points were characterized by IR simulations (harmonic approximation), from which zero-point vibrational energies and thermal corrections $(\mathrm{T}=298.15 \mathrm{~K})$ were obtained. ${ }^{50}$ The C-PCM implicit solvation model $(\varepsilon=9.08)$ was added to $\omega B 97 X$ calculations. ${ }^{51}$ Gaussian '09 was used as software. ${ }^{52}$

Supporting Information. Figures S1-S3 show selected DFTcalculated structures, while Tables S1-S3 contain the relevant bonding parameters. Figures S4-S14 show experimental IR spectra. The DFT-optimized structures are also collected in a separated .xyz file. CCDC reference numbers 1473390 (1a), 1473391 (1b), 1473392 (3a), 1473393 (3b), 1478899 (4) and 1478900 (5) contain the supplementary crystallographic data for the X-ray studies reported in this paper. These data can be obtained free of charge at www.ccdc.cam.ac.uk/conts/retrieving.html [or from the Cambridge Crystallographic Data Centre, 12, Union Road, Cambridge CB2 1EZ, UK; fax: (internat.) +44-1223/336-033; e-mail: deposit@ccdc.cam.ac.uk].

\section{Acknowledgements}

The University of Pisa, Italy, is gratefully acknowledged for financial support.

\section{References and Notes}


1 The term "ureas" will be used in order to indicate both the simplest urea, $\left(\mathrm{NH}_{2}\right)_{2} \mathrm{C}=\mathrm{O}$ and its $\mathrm{N}$-substituted derivatives.

2 (a) V. Blazek, Bregovìc, N. Basarìc and K. Mlinarìc-Majerski, Coord. Chem. Rev., 2015, 295, 80-124; (b) N. Volz and J. Clayden, Angew. Chem. Int. Ed., 2011, 50, 12148-12155; (c) P. Dydio, D. Lichosyt and J. Jurczak, Chem. Soc. Rev., 2011, 40, 2971-2985.

3 (a) M. J. McKay and H. M. Nguyen, Carbohydrate Res., 2014, 385, 18 44; (b) G. Pasello, L. Urso, P. Conte and A. Favaretto, The Oncologist, 2013, 18, 1118-1125; (c) H.-Q. Li, P.-C. Lv, T. Yan and H.-L. Zhu, Anti-Cancer Agents Med. Chem., 2009, 9, 471-480.

4 (a) P. Dydio, D. Lichosyt and J. Jurczak, Chem. Soc. Rev., 2011, 40 2971-2985; (b) J. W. Steed, Chem. Soc. Rev., 2010, 39, 3686-3699; (c) R. Custelcean, Chem. Commun., 2008, 3, 295-307.

5 (a) M. Kotke and P. R. Schreiner, (Thio)urea Organocatalysis in Hydrogen Bonding in Organic Synthesis, P. M. Pihko, Ed., WileyVCH, Weinheim, 2009, 141-351; (b) Z. Zhang and P. R. Schreiner, Chem. Soc. Rev., 2009, 38, 1187-1198; (c) T. J. Auvil, A. G. Schafer and A. E. Mattson, Eur. J. Org. Chem., 2014, 2633-2646. (d) W. Nakanishi, Related Organocatalysts (2): Urea Derivatives, in Superbases for Organic Synthesis, T. Ishikawa, Ed., Wiley, New york, 2009, 273-293.

6 (a) G. Rasul, G. K. S. Prakash and G. A. Olah, J. Org. Chem., 1994, 59, 2552-2556; (b) R. Spezia, J.-Y. Salpin, M.-P. Gaigeot, W. L. Hase, K. Song, J. Phys. Chem. A, 2009, 113, 13853-13862; (c) G. A. Olah and A. M. White, J. Am. Chem. Soc., 1968, 90, 6087-6091; (d) F. Wang, S. Ma, D. Zhang and R. G. Cooks, J. Phys. Chem. A, 1998, 102, 29882994.

7 (a) H. Wang, J. Zhao, J. Zhang, and Q. Zhu, Adv. Synth. Catal., 2011, 353, 2653-2658; (b) C. Beddie, C. E. Webster and M. B. Hall, Dalton Trans., 2005, 3542-3551; (c) R. Laudien and R. Mitzner, J. Chem. Soc., Perkin Trans. 2, 2001, 2230-2232; (d) L. Roecker, J. Akande, L. N. Elam, I. Gauga, B. W. Helton, M. C. Prewitt, A. M. Sargeson, J. H. Swango, A. C. Willis, T. Xin, and J. Xu, Inorg. Chem., 1999, 38, 1269 1275 .

8 (a) A. Müller, L. Toma, H. Bögge, C. Schäffer and A. Stammler, Angew. Chem. Int. Ed., 2005, 44, 7757-7761; (b) A. Müller, S. Roy, M. Schmidtmann and H. Bögge, Chem. Commun., 2002, 2000-2002; (c) M. H. Alizadeh, H. Eshtiagh-Hosseini, M. Mirzaei, A. R. Salimi, H Razavi, Struct. Chem, 2008, 19, 155-164; (d) C. L. Hill, D. A. Bouchard, M. Kadkhodayan, M. M. Williamson, J. A. Schmidt and E. F. Hilinsk, J. Am. Chem. Soc., 1988, 110, 5471-5479.

9 (a) Q. Appleton, L. Bernander and G. Olofsson, Tetrahedron, 1971, 27, 5921-5931; (b) G. A. Olah and A. M. White, J. Am. Chem. Soc., 1968, 90, 6087-6091.

10 (a) R. V. G. Sundera-Rao, J. W. Turley and R. Pepin-Sky, Acta Cryst., 1957, 10, 435; (b) B. Lages Rodrigues, R. Tellgren and N. G. Fernandes, Acta Cryst., 2001, B57, 353-358; (c) S. Harkema and D. Feil, Acta Cryst., 1969, B25, 589-591; (d) J. E. Worsham and W. R. Busing, Acta Cryst., 1969, B25, 572-578; (e) D. Henschel, T. Hamann, O. Moers, A. Blaschette, and P. G. Jones, Z. Naturforsch., 2002, 57b, 113-121; (f) C. J. Carmalt, L. J. Farrugia and N. C. Norman, Z. Anorg. Allg. Chem., 1995, 621, 47-56; (g) J. H. Bryden, Acta Cryst., 1957, 10, 714.

11 M. Bortoluzzi, F. Marchetti, G. Pampaloni and S. Zacchini, Chem. Commun., 2015, 51, 1323-1325.

12 (a) U. Jayarathne, J. T. Mague and J. P. Donahue, Polyhedron, 2013, 58, 13-17; (b) A. J. Nielson, P. A. Hunt, C. E. F. Rickard and P. Schwerdtfeger, J. Chem. Soc., Dalton Trans., 1997, 3311-3317; (c) N G. Connelly and W. E. Geiger, Chem. Rev., 1996, 96, 877-910; (d) E. Carmona, L. Sanchez, M. L. Poveda, Richard A. Jones and J. G. Hefner, Polyhedron, 1983, 2, 797-801; (e) P. M. Boorman, T. Chivers and K. N. Mahade, Can. J. Chem., 1975, 53, 383-388; (f) E. A. Allen, B. J. Brisdok and G. W. A. Fowles, J. Chem. Soc., 1964, 4531-4534.

13 H. Tsurugi, H. Tanahashi, H. Nishiyama, W. Fegler, T. Saito, A. Sauer, J. Okuda and K. Mashima, J. Am. Chem. Soc., 2013, 135, 5986-5989.

14 (a) M. Bortoluzzi, F. Marchetti, G. Pampaloni and S. Zacchini, Inorg. Chem., 2016, 55, 887-893; (b) M. Bortoluzzi, F. Marchetti, G. Pampaloni, S. Zacchini, Inorg. Chem., 2014, 53, 3832-3838.

15 (a) V. Pershina and B. Fricke, J. Phys. Chem., 1994, 98, 6468-6413; (b) C. H. Honeyman, A. J. Lough and I. Manners, Inorg. Chem., 1994, 33, 2988-2993; (c) D. V. Drobot and P. A. Pisarev, Russ. J. Inorg. Chem., 1981, 26, 1-8.

16 S. Dolci, F. Marchetti, G. Pampaloni and S. Zacchini, Dalton Trans., 2013, 42, 5635-5648
17 P. D. W. Boyd, M. G. Glenny, C. E.F. Rickard and A. J. Nielson, Polyhedron, 2011, 30, 632-637.

18 H. Balcar, A. Dosedlova and B. Matyska, Coll. Czech. Chem. Commun., 1986, 51, 753-762.

19 M. Bortoluzzi, F. Marchetti, M. G. Murrali, G. Pampaloni and S. Zacchini, Dalton Trans., 2015, 44, 8729-8738.

20 (a) M. Bortoluzzi, F. Guarra, F. Marchetti, G. Pampaloni and S. Zacchini, Polyhedron, 2015, 99, 141-146; (b) H. Balcar, A. Dosedlova and B. Matyska, J. Mol. Catal., 1987, 41, 367-374.

21 (a) P. Dabas, M. K. Rastogi, Asian J. Chem., 1997, 9, 445-452; (b) T. Ernst, A. El-Kholi, U. Mueller and K. Dehnicke, Z. Anorg. Allg. Chem., 1988, 566, 7-17; (c) S. Prasad and K. S. R. Krishnaiah, J. Ind. Chem. Soc., 1961, 38, 177-178.

22 A. Decken, C. Knapp, G. B. Nikiforov, J. Passmore, J. M. Rautiainen, X. Wang and X. Zeng, Chem. Eur. J., 2009, 15, 6504.

23 (a) C. Lau, A. Dietrich, M. Plate, P. Dierkes, B. Neumuller, S. Wocadlo, W. Massa, K. Harms and K. Dehnicke, Z. Anorg. Allg. Chem., 2003, 629, 473-478; (b) U. Muller, and A. El-Kholi, Acto Cryst., 1989, C45, 1727-1730. (c) G. Uhl, E. Hey, G. Becker, F. Weller and K. Dehnicke, Z. Anorg. Allg. Chem., 1983, 497, 213-223; (d) W. Elchier and H.-J. Selfert, Z. Anorg. Allg. Chem., 1977, 431, 123-133.

24 (a) C. M. Prosser-McCartha, M. Kadkhodayan, M. M. Williamson, D. A. Bouchard and C. L. Hill, J. Chem. Soc., Chem. Commun., 1986 1747-1748; (b) J. A. Schmidt and E. F. Hillinski, J. Am. Chem. Soc., 1988, 110, 5471-5479.

25 P. Gilli, V. Bertolasi, V. Ferretti and G. Gilli, J. Am. Chem. Soc., 1994 , 116, 909-915.

26 F. H. Allen, O. Kennard, D. G. Watson, L. Brammer, A. G. Orpen, and R. Taylor, J. Chem. Soc., Perkin Trans. 2, 1987, S1-S19.

27 (a) L. Cecinska, W. Morgenroth, C. Paulmann, D. Jayatilaka and B Dittrich, CrystEngComm, 2013, 15, 2084-2090; (b) K. Uehara, K. Fukaya and N. Mizuno, Angew. Chem. Int. Ed., 2012, 51, 7715-7718; (c) K. Uehara and N. Mizuno, J. Am. Chem. Soc., 2011, 133, 16221625; (d) W. Dannecker, J. Kopf and H. Rust, Cryst. Struct. Commun., $1979,8,429-432$

28 (a) R. S. Nyhlom, J. Inorg. Nucl. Chem., 1958, 8, 401-422; (b) B. Figgis, J. Inorg. Nucl. Chem., 1958, 8, 476-482.

29 The calculated $\Delta \mathrm{G}$ for the reaction $\left\{[\mathrm{dpuH}]^{+}+\mathrm{dpu} \rightarrow[(O-H-O)\right.$ $\left.(\mathrm{dpu})_{2}\right]^{+}$, is $-7.4 \mathrm{kcal} \mathrm{mol}^{-1}$.

30 T. Nishikata, A. R. Abela and B. H. Lipshutz, Angew. Chem. Int. Ed., 2010, 49, 781-784.

31 (a) C. A. Dodds, M. D. Spicer and T. Tuttle, Organometallics, 2011, 30, 6262-6269; (b) R. J. Fante and P. E. Hoggard, Trans. Met. Chem., 2008, 33, 825-828; (c) D. A. Danilov, V. A. Volkovich, B. D. Vasin, I. B. Polovov and T. R. Griffiths, Z. Naturforsch., 2007, 62a, 739-744.

32 The most stable electronic configuration is the quartet one (i.e., the organic cation is in triplet state), by about $14.0 \mathrm{kcal} \mathrm{mol}^{-1}$ with respect to the doublet state.

33 The triplet state of the $[\mathrm{dpu}]^{2+}$ cation is more stable than the singlet one by $23.5 \mathrm{kcal} \mathrm{mol}^{-1}$

34 The reaction $\left\{[\mathrm{PhNC}(\mathrm{O}) \mathrm{NHPh}]^{+}+\mathrm{CH}_{2} \mathrm{Cl}_{2} \rightarrow[\mathrm{dpu}]^{+}+\mathrm{CHCl}_{2}\right\}$ is only slightly endoergonic, $\Delta \mathrm{G}=2.8 \mathrm{kcal} \mathrm{mol}^{-1}$.

35 The addition of water to the reaction mixtures facilitates the release of the organic material from the highly oxophilic metal species, and allows the spectroscopic identification of the former. This strategy has been successfully adopted by ourselves in previous works, having proved that $\mathrm{H}_{2} \mathrm{O}$ is generally inert towards ligand activation reactions [see ref. 16,36].

36 S. Dolci, F. Marchetti, G. Pampaloni and S. Zacchini, Dalton Trans., 2010, 39, 5367-5376.

37 (a) C. Persson and C. Andersson, Polyhedron, 1991, 10, 2089-2093; (b) P. M. Boorman, N. N. Greenwood, M. A. Hildon and R. V. Parish, J. Chem. Soc. (A), 1968, 2002-2004.

38 T. M. Brown, E. L. McCann, Inorg. Chem., 1968, 7, 1227-1229.

39 (a) A. Okrut and C. Feldmann, Z. Kristallogr. New Cryst. Struct., 2008 , 223, 21; (b) A. Okrut and C. Feldmann, Z. Anorg. Allg. Chem., 2007, 633, 2144-2146; (c) M. Karl, G. Seybert, W. Massa and K. Dehnicke, Z. Naturforsch. B, 1999, 54, 1609-1610; (d) B. Siewert and U. Muller, Z. Anorg. Allg. Chem., 1992, 609, 77-81.

40 (a) N. A. Ovchinnikova, A. E. Sinyakov, V. S. Sergienko, G. G. Alexandrov, M. Yu. Burtzev, J. Coord. Chem., 2003, 56, 995-1002; (b) V. S. Sergienko, V. L. Abramenko, A. B. Ilyukhin, Russ. J. Inorg. Chem., 1997, 42, 945-951; (c) I. W. Bassi, R. Scordamaglia, J. Organomet. Chem., 1975, 99, 127-134 
41 G. A. Jeffrey, An Introduction to Hydrogen Bonding, Oxford University Press, Oxford, 1997.

42 V. C. Gibson, T. P. Kee, A. Shaw, Polyhedron, 1990, 9, 2293-2298.

43 E. König, Magnetische Eigenschaften der Koordinations- und Metallorganischen Verbindungen der Übergangselemente in LandoltBörnstein, Zahlenwerte und Funktionen aus Naturwissenschaften und Technik, 6th Ed., Springer-Verlag, Berlin, Göttingen, Heidelberg, 1966, 2, 16.

44 W. Willker, D. Leibfritz, R. Kerssebaum and W. Bermel, Magn. Reson. Chem., 1993, 31, 287-292.

45 D. A. Skoog, D. M. West and F. J. Holler, Fundamentals of Analytical Chemistry, 7th Edition, Thomson Learning, Inc, USA, 1996.

46 G. M. Sheldrick, SADABS, University of Göttingen, Göttingen, Germany, 1996.

47 G. M. Sheldrick, SHELX97, University of Gottingen, Göttingen, Germany, 1997.

48 (a) Y. Minenkov, Å. Singstad, G. Occhipinti and V. R. Jensen, Dalton Trans., 2012, 41, 5526-5541; (b) J.-D. Chai and M. Head-Gordon, Phys. Chem. Chem. Phys., 2008, 10, 6615-6620; (c) I. C. Gerber and J. G. Ángyán, Chem. Phys. Lett., 2005, 415, 100-105.

49 (a) L. E. Roy, P. J. Hay and R. L. Martin, J. Chem. Theory Comput., 2008, 4, 1029-1031. (b) M. M. Francl, W. J. Pietro, W. J. Hehre, J. S. Binkley, D. J. DeFrees, J. A. Pople and M. S. Gordon, J. Chem. Phys., 1982, 77, 3654-3665.

50 C. J. Cramer, Essentials of Computational Chemistry, $2^{\text {nd }}$ Edition, Wiley, Chichester, 2004

51 (a) M. Cossi, N. Rega, G. Scalmani and V. Barone, J. Comput. Chem. 2003, 24, 669-681; (b) V. Barone and M. Cossi, J. Phys. Chem. A, 1998, 102, 1995-2001.

52 Gaussian 09, Revision E.01, M. J. Frisch, G. W. Trucks, H. B. Schlegel, G. E. Scuseria, M. A. Robb, J. R. Cheeseman, G. Scalmani, V. Barone, B. Mennucci, G. A. Petersson, H. Nakatsuji, M. Caricato, X. Li, H. P. Hratchian, A. F. Izmaylov, J. Bloino, G. Zheng, J. L. Sonnenberg, M. Hada, M. Ehara, K. Toyota, R. Fukuda, J. Hasegawa, M. Ishida, T. Nakajima, Y. Honda, O. Kitao, H. Nakai, T. Vreven, J. A Montgomery, Jr., J. E. Peralta, F. Ogliaro, M. Bearpark, J. J. Heyd, E. Brothers, K. N. Kudin, V. N. Staroverov, R. Kobayashi, J. Normand, K. Raghavachari, A. Rendell, J. C. Burant, S. S. Iyengar, J. Tomasi, M Cossi, N. Rega, J. M. Millam, M. Klene, J. E. Knox, J. B. Cross, V. Bakken, C. Adamo, J. Jaramillo, R. Gomperts, R. E. Stratmann, O Yazyev, A. J. Austin, R. Cammi, C. Pomelli, J. W. Ochterski, R. L. Martin, K. Morokuma, V. G. Zakrzewski, G. A. Voth, P. Salvador, J. J. Dannenberg, S. Dapprich, A. D. Daniels, Ö. Farkas, J. B. Foresman, J. V. Ortiz, J. Cioslowski, and D. J. Fox, Gaussian, Inc., Wallingford CT, 2009 
Table 6. Crystal data and experimental details for $\left[(\mathrm{tmu})_{2} \mathrm{H}\right]\left[\mathrm{WCl}_{6}\right], \mathbf{1 a},\left[(\mathrm{dpu})_{2} \mathrm{H}\right]\left[\mathrm{WCl}_{6}\right], \mathbf{1 b}, \mathrm{WCl}_{5}(\mathrm{dmu}), \mathbf{3 a}, \mathbf{a n d} \mathrm{WCl}_{5}(\mathrm{tmu}), \mathbf{3 b}, \mathrm{WOCl}_{4}(\mathrm{teuH})$, 4, and $\mathrm{WOCl}_{4}(\mathrm{dmu}), 5$.

\begin{tabular}{|c|c|c|c|c|c|c|}
\hline Complex & $1 \mathbf{a}$ & $1 \mathrm{~b}$ & $\mathbf{3 a}$ & 3b & 4 & $\mathbf{5}$ \\
\hline Formula & $\mathrm{C}_{10} \mathrm{H}_{25} \mathrm{Cl}_{6} \mathrm{~N}_{4} \mathrm{O}_{2} \mathrm{~W}$ & $\mathrm{C}_{26} \mathrm{H}_{25} \mathrm{Cl}_{6} \mathrm{~N}_{4} \mathrm{O}_{2} \mathrm{~W}$ & $\mathrm{C}_{3} \mathrm{H}_{8} \mathrm{Cl}_{5} \mathrm{~N}_{2} \mathrm{OW}$ & $\mathrm{C}_{5} \mathrm{H}_{12} \mathrm{Cl}_{5} \mathrm{~N}_{2} \mathrm{OW}$ & $\mathrm{C} 9 \mathrm{H} 21 \mathrm{C} 14 \mathrm{~N} 2 \mathrm{O} 2 \mathrm{~W}$ & $\mathrm{C} 3 \mathrm{H} 8 \mathrm{Cl} 4 \mathrm{~N} 2 \mathrm{O} 2 \mathrm{~W}$ \\
\hline$F w$ & 629.89 & 822.05 & 449.21 & 477.27 & 514.93 & 429.76 \\
\hline $\mathrm{T}, \mathrm{K}$ & $100(2)$ & $100(2)$ & $100(2)$ & $100(2)$ & 0.71073 & 0.71073 \\
\hline$\lambda, \AA$ & 0.71073 & 0.71073 & 0.71073 & 0.71073 & $100(2)$ & $100(2)$ \\
\hline Crystal system & Monoclinic & Triclinic & Orthorhombic & Monoclinic & Monoclinic & Monoclinic \\
\hline Space group & $P 2{ }_{1} / c$ & $P^{\overline{\mathbf{1}}}$ & $P 2{ }_{1} 2_{1} 2_{1}$ & $P 2_{1} / n$ & $\mathrm{P} 21 / \mathrm{n}$ & $\mathrm{P} 21 / \mathrm{n}$ \\
\hline$a, \AA$ & $8.8051(16)$ & $10.165(4)$ & $10.180(3)$ & $9.1938(18)$ & $9.7817(6)$ & $9.483(2)$ \\
\hline$b, \AA$ & $13.364(2)$ & $11.202(4)$ & $15.365(4)$ & $14.574(3)$ & $12.5746(7)$ & $10.127(2)$ \\
\hline$c, \AA$ & $9.6474(17)$ & $15.614(8)$ & $22.009(6)$ & $9.857(2)$ & $13.7251(8)$ & $11.202(2)$ \\
\hline$\alpha,{ }^{\circ}$ & 90 & $97.210(6)$ & 90 & 90 & 09 & 09 \\
\hline$\beta, \circ$ & $107.100(2)$ & $105.984(6)$ & 90 & $96.519(2)$ & $91.9790(10)$ & $89.971(2)$ \\
\hline$\gamma, \circ$ & 90 & $114.048(4)$ & 90 & 90 & 90 & 90 \\
\hline Cell Volume, $\AA^{3}$ & $1085.0(3)$ & $1502.4(11)$ & $3442.5(17)$ & $1312.3(5)$ & $1687.19(17)$ & $1075.8(4)$ \\
\hline $\mathrm{Z}$ & 2 & 2 & 12 & 4 & 4 & 4 \\
\hline$D_{c}, \mathrm{~g} \mathrm{~cm}^{-3}$ & 1.928 & 1.817 & 2.600 & 2.416 & 2.027 & 2.654 \\
\hline$\mu, \mathrm{mm}^{-1}$ & 6.072 & 4.410 & 11.190 & 9.793 & 7.476 & 11.696 \\
\hline Crystal size, mm & $0.16 \times 0.15 \times 0.12$ & $0.16 \times 0.14 \times 0.10$ & $0.19 \times 0.13 \times 0.10$ & $0.22 \times 0.16 \times 0.13$ & $0.22 \times 0.19 \times 0.12$ & $0.16 \times 0.13 \times 0.10$ \\
\hline$\theta$ limits, $^{\circ}$ & $2.42-27.00$ & $2.07-26.00$ & $1.62-25.03$ & $2.51-27.00$ & $2.20-28.00$ & $1.82-25.49$ \\
\hline Reflections collected & 10402 & 14858 & 30675 & 10541 & 19303 & 9529 \\
\hline Independent reflections & $2352\left[R_{\mathrm{int}}=0.0295\right]$ & $5871\left[R_{\mathrm{int}}=0.0539\right]$ & $6061\left[R_{\mathrm{int}}=0.1196\right]$ & $2858\left[R_{\mathrm{int}}=0.0557\right]$ & $\begin{array}{c}40246[\mathrm{Rint}= \\
0.0373]\end{array}$ & $\begin{array}{c}1975[\text { Rint }= \\
0.0571]\end{array}$ \\
\hline $\begin{array}{l}\text { Data / restraints } \\
\text { /parameters }\end{array}$ & $2352 / 5 / 109$ & $5871 / 209 / 367$ & $6061 / 102 / 344$ & $2858 / 0 / 131$ & $4024 / 1 / 163$ & 1975 / $107 / 110$ \\
\hline Goodness of fit on $\mathrm{F}^{2}$ & 1.097 & 0.979 & 1.018 & 1.019 & 1.038 & 1.225 \\
\hline$R_{1}(I>2 \sigma(I))$ & 0.0339 & 0.372 & 0.458 & 0.0295 & 0.0203 & 0.0604 \\
\hline$w R_{2}$ (all data) & 0.0891 & 0.0888 & 0.997 & 0.0653 & 0.0433 & 0.1470 \\
\hline $\begin{array}{l}\text { Largest diff. peak } \\
\text { and hole, e } \AA^{-3}\end{array}$ & $2.577 /-2.509$ & $1.539 /-2.082$ & $2.483 /-1.670$ & $1.428 /-0.763$ & $0.922 /-0.519$ & $4.439 /-2.745$ \\
\hline
\end{tabular}

